\title{
DESCENT AND DIFFUSION IN LANGUAGE DIVERSIFICATION: A STUDY OF WESTERN NUMIC DIALECTOLOGY ${ }^{1}$
}

\author{
Molly Babel, Andrew Garrett, Michael J. Houser, \\ AND MAZIAR TOOSARVANDANI
}

The two branches of Western Numic are the Mono and Northern Paiute languages. We argue that this taxonomic structure did not arise as usually assumed in historical linguistics, through increased differentiation brought about by changes internal to each branch, but rather that diffusion between Western and Central Numic played a crucial role in forming the Western Numic family tree. More generally, we suggest that diffusion plays a greater role in language diversification than is usually recognized.

[KEYWORDs: dialectology, diffusion, Numic, phylogeny, subgrouping]

1. Introduction. The emergence of language boundaries in a dialect network raises a venerable question in historical linguistics. How do discrete language differences arise in populations in which speech variation is relatively continuous along social or geographic dimensions? Over longer time spans, such discrete boundaries yield the sharply differentiated branches of a language family. What, then, is the origin of the family-tree effect in language relationships?

${ }^{1}$ An early version of this paper was presented at the 2007 Annual Meeting of the Society for the Study of the Indigenous Languages of the Americas (SSILA). For comments, discussion, and suggestions at various stages of our work we are grateful to the SSILA audience, to Claire Bowern, Victor Golla, Chris Loether, Mark Hale, Jane Hill, John McLaughlin, Sally Thomason, Tim Thornes, and three IJAL reviewers, and to our fellow participants in the 2005-2006 field methods course at the University of California, Berkeley: Erin Haynes, Reiko Kataoka, Fanny Liu, Nicole Marcus, Ruth Rouvier, Ange Strom-Weber, and Corey Yoquelet. For teaching us about their language, Mono Lake Northern Paiute, we are especially indebted to Grace Dick, Leona Dick, Morris Jack, Elaine Lundy, Edith McCann, Meg McDonald, and Madeline Stevens.

Transcriptions use IPA broadly except that $\check{c}=\left[\mathrm{t} \int\right] ; y=[\mathrm{j}]$; lenis $b, d, g$ are $[\mathrm{b}] \sim[\beta],[\mathrm{r}],[\mathrm{g}]$ $\sim[\gamma]$ respectively; and double letters write long vowels. The following abbreviations appear in glosses: 1, 2, 3 = first, second, third person; $4=$ fourth (indefinite) person; comPL $=$ completive; CONT $=$ continuative $;$ DIST $=$ distal $; \mathrm{DL}=$ dual $; \mathrm{EXCL}=$ exclusive $; \mathrm{FOC}=$ focus; FUT $=$ future INCL $=$ inclusive; IP = instrumental prefix; LOC = locative; $\mathrm{MOT}=$ associated motion; $\mathrm{NOM}=$ nominalizer; NRPROX $=$ near-proximal; OBJ = objective; $\mathrm{PL}=$ plural; $\mathrm{POSS}=$ possessive $; \mathrm{PROX}=$ proximal $; \mathrm{Q}=$ question particle; RED = reduplicant; REP = repetitive; RSTLV $=$ resultative; SUBJ $=$ subjective. See Appendix A for language name abbreviations other than PN = Proto-Numic, PUA = Proto-UtoAztecan, Rm = Rarámuri (no single ISO code) (data quoted from Gabriela Caballero, personal communication), and $\mathrm{Tb}=$ Tübatulabal (ISO code: tub) (data quoted from Voegelin 1958).

Affiliations for the authors of this paper are: Babel-University of British Columbia; Garrett-University of CAlifornia, Berkeley; Houser-Berkeley, California; ToosarvandaniUniversity of California, Santa Cruz.

[IJAL, vol. 79, no. 4, October 2013, pp. 445-89]

(C) 2013 by The University of Chicago. All rights reserved. 0020-7071/2013/7904-0001\$10.00 
It is useful here to introduce terms (borrowed from biology) for two kinds of language groups. We use the term CLADE to refer to a group consisting of all the languages or dialects descended from a single ancestor; for example, all the languages descended from Proto-Oceanic comprise the Oceanic clade. The term TAXON refers to a group of related languages or dialects sharing a significant set of features. The features that define a taxon may in principle be archaisms or innovations. If one language in a clade has many innovations and the others are conservative, the latter comprise a taxon defined by their shared archaisms. Such a taxon is not a clade, since its members' last common ancestor has a descendant that does not belong to the taxon. Our concern here is with taxa whose defining features are innovations, which we call APOMORPHIC TAXA. ${ }^{2}$ While a clade may be and usually is an apomorphic taxon (if it has innovations relative to some more remote ancestor), it is possible in principle for an apomorphic taxon's shared features to have sources other than inheritance from its members' last common ancestor. Such a taxon is not a clade. To restate our basic question: how do apomorphic taxa arise?

This question is answered differently in different models of linguistic diversification. In the classic family-tree model, insofar as this is meant to represent actual historical processes (not just their results), apomorphic taxa are assumed to arise through geographic or sociolinguistic isolation. For example, if a population moves into a new area and then has less communication with another that remained behind, the speech of the two populations may diverge as changes spread through one but not the other. Eventually, enough innovations may distinguish their two speech varieties that they are clearly distinct taxa, and later still their respective descendants may be classified in different branches of a language family. Hock (1991:450) states the model clearly: "splits seem to result only when originally closely affiliated dialects become separated ... such that they cease to be mutually intelligible and become different languages." This pattern of linguistic diversification is known from innumerable examples, such as the French dialects of North America or the

\footnotetext{
${ }^{2}$ We adapt this name from the term APOMORPHY, which in biological cladistics refers to a feature shared by a group that originated in the last common ancestor of that group. Our use of the term is different; we do not presuppose that the innovations that define an apomorphic taxon originated in the last common ancestor of its members.

Note that our definitions, strictly interpreted, permit incompatible coexisting taxa; the Germanic languages clearly form a taxon, but English and French might also comprise an apomorphic taxon as we defined the term, since innovations of each language have passed into the other. To exclude such cases from consideration, we could insist on a unique taxonomy: an English-French taxon would be ruled out because English shares more (or more significant) innovations with other Germanic languages than with French. Our main goal is to have terminology for members of a historically oriented language taxonomy that do not necessarily comprise a clade. We have tried to be clear, but we know that some readers may find our terms baroque, while others will see their imprecision; they are not meant to replace historical linguists' judgments or expertise.
} 
Austronesian language family across the islands of the Pacific and Indian oceans; in biology, it corresponds to speciation brought about by complete or partial population isolation. ${ }^{3}$

In models that explicitly posit dialect networks as starting points, two mechanisms have been invoked to explain the emergence of sharp language differentiation. One is called NETWORK BREAKING by Ross (1988) and Pawley and Ross (1995): a dialect becomes isolated from other dialects in its network and accumulates innovations that are not shared across the network; this is effectively the same process as is posited in the classic family-tree model. A second and somewhat different mechanism, which can be called NETWORK PRUNING, was proposed by Schmidt (1872) in his original formulation of the wave model. Discussing Indo-European in particular, he argues that sharply distinct languages and the eventual family-tree effect can arise out of an earlier dialect network when expanding dialects replace their neighbors. If enough intermediate dialects are pruned, the remaining dialects will be sharply distinct because no pair of them was especially close in the original network. In this way, Schmidt suggests, discrete language boundaries can arise from an original continuously varying dialect network. This pattern of diversification is clearly attested in cases such as Latin, whose spread throughout Italy eradicated the other languages belonging to the Italic branch of Indo-European, or koine Greek, which supplanted most of the local dialects of Greek as it spread in the Hellenistic era.

In practice, the family-tree, network-breaking, and network-pruning models share one important assumption: apomorphic taxa are clades. "It is assumed," as Campbell (2004:190-91) puts it, that "a shared innovation is the result of a change which took place in a single daughter language which then subsequently diversified into daughters of its own, each of which inherits the results of the change." Pawley and Ross (1995:54) write similarly that if "all member languages of [a] subgroup exclusively share a set of innovations," we may infer that "these innovations occurred in the language ancestral to them." So, for example, the innovations shared by all Italic languages are assumed to have taken place in a Proto-Italic period, before Latin underwent changes distinguishing it from other Italic languages. This does not mean that Proto-Italic must have been homogeneous or devoid of variation, or that no changes diffused later among already differentiated Italic languages. But neither the classic family-tree model nor its network-breaking variant, nor Schmidt's network-pruning model, takes diversity internal to an ancestral

\footnotetext{
${ }^{3}$ We do not mean to imply that the Austronesian spread, let alone that of extra-hexagonal French, involved complete population isolation; it is now well known, for example, that population and therefore linguistic contacts occurred even across great distances in the Pacific after the initial spread of Austronesian. The point is that such contacts were not numerous or intense enough to inhibit linguistic differentiation.
} 
population or subsequent diffusional changes as significant factors in language diversification.

The view that shared innovations reflect descent from a single common ancestor in which those innovations occurred, rather than diffusion across already differentiated speech varieties, has also been maintained from a sociolinguistic perspective. Discussing changes in American English, Labov (2007:347) writes that the "primary source" of differences among related dialects or languages "is the transmission (and incrementation) of change within the speech community" rather than the spread of changes across speech communities. In other words, dialects and languages diverge mainly as a result of accumulating dialect-internal changes. ${ }^{4}$

We defend a different view in this paper: apomorphic taxa need not be clades; they may instead be formed by diffusional processes. That is, the shared innovations defining an apomorphic taxon may result from diffusion across an already well differentiated population. To be sure, since actual populations vary linguistically, all innovations must spread across differentiated populations. The general assumption, however, has been that the differences (say, among speech varieties in the Proto-Italic population) are relatively minor, or at any rate that they do not relate systematically to differences that assume significance in the later differentiation of descendant languages. From a sociolinguistic point of view, this is again supported by Labov (2007:347): the ordinary spread of innovations (as opposed to diffusional processes that are structurally restricted and prone to simplification) is confined to "a speech community with well-defined limits, a common structural base, and a unified set of sociolinguistic norms." 5 We argue instead that innovations spreading across well-defined speech boundaries-a staple of the language-contact literature, not an original finding of our research-are sometimes also the primary source of linguistic differentiation.

This general phenomenon has at least two distinct profiles. In one profile, identified by Geraghty (1983) for Fijian and suggested by Garrett (1999; 2006) for Greek and other Indo-European branches, linguistic taxa are formed by mutual assimilation among adjacent dialects in a network. Some of these dialects might previously have shared more features with other neighbors than with each other, but after a period of convergence they form a taxon with apparent common innovations. ${ }^{6}$ This profile can be called NETWORK CON-

\footnotetext{
${ }^{4}$ Noting that even European dialect studies show different results, Labov does acknowledge (2007:348) that his findings may depend on the special circumstances of North American English. If so, they are a fortiori unlikely to apply generally to the non-western and pre-industrial settings in which all but a tiny handful of the world's languages have been spoken.

5 This conception of the speech community is of limited cross-cultural applicability, especially in small-scale hunter-gatherer societies such as those we discuss here; see Hill (1978).

6 This is distinct from koineization as defined by Ross (2007:134): "dialects or closely related languages spoken in a newly forged speech community become increasingly similar until
} 
VERGENCE; it yields a tree-like pattern because dialect clusters in the original network have coalesced into taxa by sharing innovations. Crucially, some of the differences among dialects in such taxa are older than their commonalities.

In a second profile, which we describe here, diffusional processes do not produce a taxon that encompasses all the participating dialects. Rather, because diffusion crosses a major dialect boundary, it yields an apomorphic taxon on one side of the boundary; a taxon emerges as linguistic features spread from one dialect network into a neighboring one. Specifically, we examine the Western branch of Numic, itself traditionally subdivided into Mono and Northern Paiute. These two languages or sets of dialects are said to be mutually unintelligible. Certainly, the dialects in each set share many linguistic innovations and thus form an apomorphic taxon. But we argue that they are not clades, and that features characterizing the two taxa reflect diffusion into Western Numic from the adjacent Central Numic dialect network. ${ }^{7}$

We should emphasize that there is nothing new in the claim that linguistic features have diffused across Numic dialect and language boundaries, nor even that such diffused features can play a role in dialect or language differentiation. Diffusional effects within Central Numic have often been emphasized (Miller 1970 and Miller, Tanner, and Foley 1971), and McLaughlin (2000) argues that a phonological change borrowed from Colorado River Numic into Comanche is a salient perceptual feature distinguishing the latter from its sister Shoshoni. What we claim here is that diffusion of multiple features across a major boundary can suffice to generate language differentiation. In this case, diffusion across the Western-Central Numic boundary helped create the taxa of Western Numic.

\section{Numic languages.}

2.1. Dialectology and sociolinguistics. Numic was identified as a branch of Uto-Aztecan by Kroeber (1907) on the basis of lexical isoglosses. Numic languages are spoken in an area extending across the Great Basin from eastern California into Nevada, Oregon, Idaho, Wyoming, Utah, and

a single common language emerges." The difference is that convergence does not result in a "single common language" in cases such as the one we discuss, perhaps because there is no "newly forged speech community."

${ }^{7}$ Similar cases are probably not rare. For example, in Eastern Algonquian, Goddard (2008) suggests that much of the differentiation of Western vs. Eastern Mahican is due to one of the two dialects (but crucially not both) adopting phonological and morphological features from neighboring languages. Likewise, within a subgroup of Western Oceanic, Ross (1988:257-314) has suggested that the Northwest Solomonic and South New Ireland language groups form a clade, but that after the migration of Northwest Solomonic speakers, innovations diffused across the remaining languages of New Ireland, yielding what we would call an apomorphic taxon that is not a clade. 
Colorado. ${ }^{8}$ The other Northern Uto-Aztecan languages are Hopi (ISO code: hop), Tübatulabal (ISO code: tub), and the Takic languages of southern California.

Numic has three obvious branches, each of which is usually divided into two or three languages, as shown in (1), following Merriam (1955) and Lamb (1958). ${ }^{9}$

(1) Numic languages (consensus classification)

(1a) Western Numic: Mono, Northern Paiute

(1b) Central Numic: Timbisha, Shoshoni, Comanche

(1c) Southern Numic: Kawaiisu, Colorado River Numic

Figure 1 gives a partial Numic language map, focussing on Western Numic and its neighbors; figure 2 shows more detail around the Mono area. In Appendix A, we give a fuller dialect classification, a list of sources, and language name abbreviations.

A more articulated family tree is proposed by Iannucci (1973:89) and Freeze and Iannucci (1979). They argue that Central and Southern Numic form an Eastern Numic clade and that the Western-Eastern split is the primary division in Numic. In addition to lexical isoglosses (for which it is harder to identify the direction of change), Freeze and Iannucci identify several phonological and morphological innovations defining Eastern Numic. ${ }^{10}$ We adopt and occasionally refer to their more articulated structure, and we also identify additional Eastern Numic changes. We should add that we take no position on whether Numic branches are true clades or were themselves formed by diffusional processes like those we describe in this paper. Here, we focus primarily on the internal diversification of Western Numic.

Within Western Numic, the Mono-Northern Paiute language boundary (figs. 1 and 2) is generally seen as sharp. Between the northernmost Mono area and the southernmost Northern Paiute area, Merriam (1955:169) writes, "a barrier of lofty mountains intervenes and the languages are materially different." Lamb (1958:96) finds the same "very clear" linguistic boundary "marked by

\footnotetext{
${ }^{8}$ Comanche, whose speakers moved into Texas, Oklahoma, and New Mexico in the eighteenth century, is the only Numic language spoken outside this contiguous area.

9 We also refer to the Western Shoshoni, Northern Shoshoni, and Eastern Shoshoni dialects. See Miller, Elzinga, and McLaughlin (2005: 414-15) on the language names "Timbisha" (a.k.a. Panamint, Tümpisa Shoshoni, or Koso Shoshoni) and "Colorado River Numic" (comprising the Chemehuevi, Southern Paiute, and Ute dialects).

${ }^{10}$ Morphological changes include the loss of pronominal prefixes preserved in Western Numic (and outside Numic in Hopi) and the creation of a complex nominal absolutive suffix *-pi-ttsi. On Bettinger and Baumhoff's (1982) view that Proto-Numic was spoken in Owens Valley, Eastern Numic could represent an early migration into the area of Death Valley before further differentiation into Central and Southern Numic.
} 




FIG. 1.-Partial map of Numic languages.

a number of important differences ... The degree of mutual intelligibility is so slight that it is best to consider the dialects as belonging to two separate languages." Significantly, Lamb also notes a "marked similarity" among Northern Paiute dialects.

The asymmetry Lamb describes in Western Numic is typical of Numic as a whole. In each branch, an inner language (such as Mono) is distributed over a relatively small area and another language (such as Northern Paiute) extends 


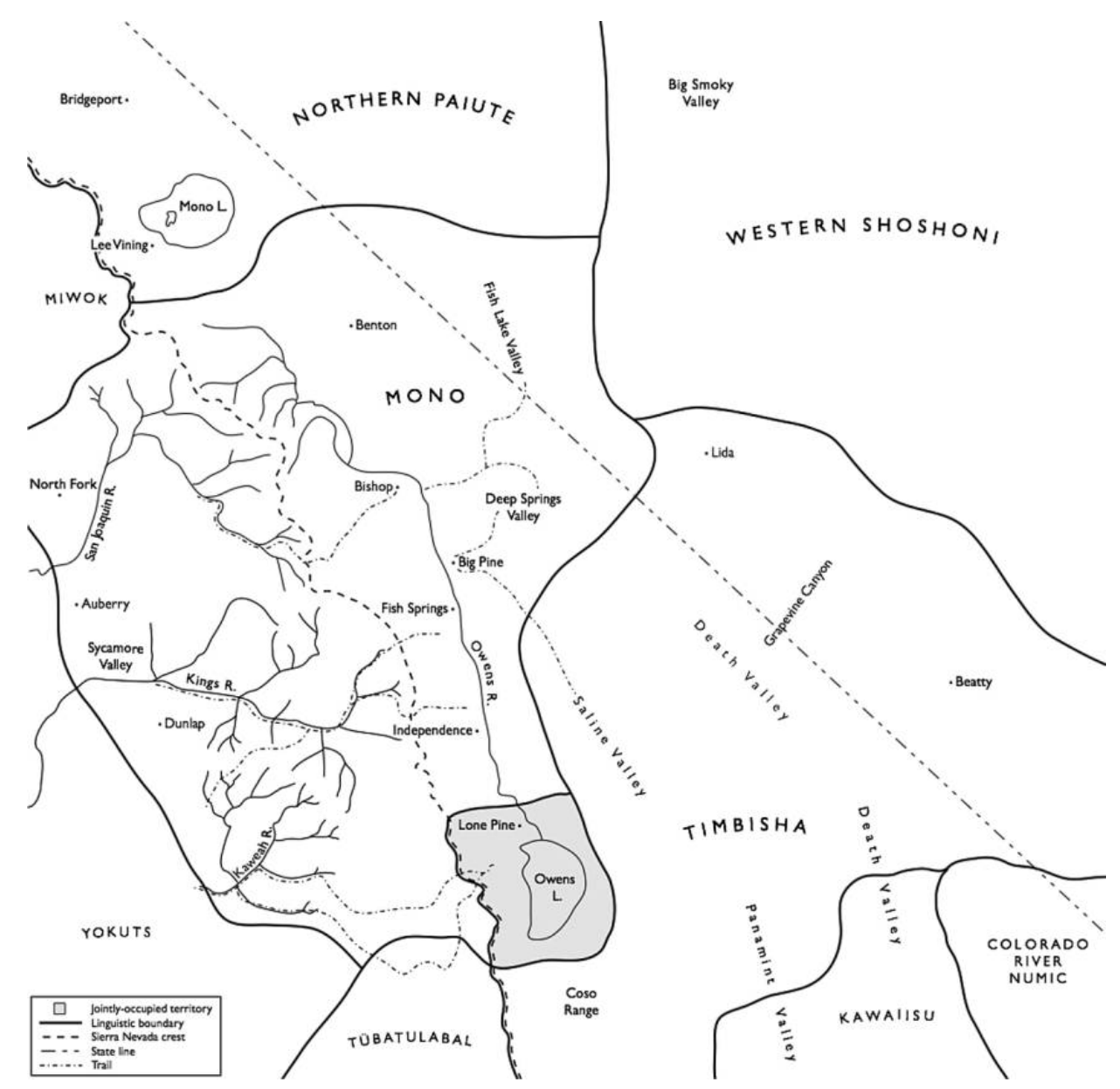

FIG. 2.-Detail of area centered on Owens Valley (adapted from Steward 1933; 1938).

outward over a much larger area; the inner languages are generally said to be more diverse than the outer languages. The Numic languages thus resemble a fan with its base in the southwest corner of the Great Basin.

This pattern has been explained ecologically and through population history; the explanations are not incompatible and no doubt both are valid. An account of the first type is offered by Liljeblad and Fowler (1986:412), writing about the largest area of Mono speech. They note that a favorable physical environment "enabled the Owens Valley Paiutes to live a semisettled life that was possible for no other Numic-speaking people. Permanent settlements and subgroupings of longer duration gave rise to local dialects that despite shifts in population have proved to be remarkably stable." Conversely, across the large area of the Great Basin, Shaul (1986:415) suggests that relative linguistic uniformity could have been maintained "as an important adaptive tactic" in 
response to the ecological and sociolinguistic pressures described as follows by Hill (1978:10): a "complex mosaic of individual variation apparently reflects the very high mobility of the Shoshoni in precontact times, which has continued until the present. Linguistic innovations could not develop regional loci, but were constantly being reassorted in the kaleidoscope of long-distance individual and group movements." 11

A second explanation is diachronic. Lamb (1958:99) suggests that early Numic populations occupied the southwestern Great Basin "until perhaps one thousand years ago," when they began expanding into their present territories; the inner languages thus have more dialect diversity than the outer languages. This model is accepted by most linguists (Miller 1986) and some archaeologists (Bettinger and Baumhoff 1982), and is said to be supported by genetic data (Kaestle and Smith 2001). ${ }^{12}$ Certainly, a recent rapid expansion would explain the relatively undifferentiated nature of outer languages like Northern Paiute. But in the absence of further sociohistorical detail, this does not explain the emergence of a discrete language boundary separating Mono and Northern Paiute; by itself, it predicts continuous variation (decreasing as one moves from south to north). The absence of a comparably clear boundary separating Timbisha and Shoshoni within Central Numic highlights the problem for Western Numic. ${ }^{13}$

The inhabitants of the Great Basin and adjacent areas were highly mobile, interacting across and within linguistic boundaries. Across the WesternCentral Numic boundary, for example, in the southern area, Steward (1933; 1938) and Liljeblad and Fowler (1986) describe intermarriage, population exchange, and economic cooperation. Throughout the northern area, too, bilingualism, intermarriage, exchange, and cooperative hunts, festivals, and dances are reported by Steward (1938), Fowler and Liljeblad (1986), and Murphy and Murphy (1986).

Within Western Numic there was also substantial contact. Trade between Owens Valley and the Mono Lake area is reported by Davis (1965); trade between those areas and Mono territory west of the Sierra Nevada crest is reported by Steward (1933) and Davis (1965). Gifford (1932) and Davis (1965) also describe summer travel, year-long temporary relocations, and intermarriage between Mono speakers to the west of the Sierra Nevada crest

11 This suggestion seems very plausible, though we do not agree with Shaul's specific view that such pressures could have maintained the same uniformity "over millennia" (1986:415).

12 On the archaeological evidence, see Madsen and Rhode (1994) and the review of Hill (forthcoming).

13 Miller, Tanner, and Foley (1971) found evidence for a linguistic boundary between Shoshoni and Timbisha, but based only on lexicostatistical data in which only four lexical items showed sharp isoglosses ('neck', 'short', 'leaf', and 'dog'; isoglosses overlap in other words). The grammatical profiles of Timbisha and Shoshoni are more similar than those of Mono and Northern Paiute. 
TABLE 1

Correspondences Involving $* a, * i$, And $* a i$

\begin{tabular}{|c|c|c|c|c|c|}
\hline Mono & NP & $\mathrm{CN}$ & $\mathrm{Kw}$ & $\mathrm{CR}$ & Example \\
\hline$a$ & $a(\mathrm{SNP}$ tabu?u) & $a($ WSh tapu $)$ & $a(t a v u-)$ & $a(t a v u-)$ & $\begin{array}{l}\text { *tapu 'cottontail } \\
\text { rabbit' }\end{array}$ \\
\hline$i$ & $i(m u b i)$ & $i$ (WSh mupi) & $i(m u v i-)$ & $i$ (movi-) & *mupi 'nose' \\
\hline$a \sim * a i(>a i \sim e)$ & $a$ & $* a i(>a i \sim e)$ & $a i \sim a$ & $a$ & $(11)-(13)$ \\
\hline$i \sim * a i(>a i \sim e)$ & $i$ & $* a i(>a i \sim e)$ & $a i \sim a$ & $a$ & (14) and (15) \\
\hline
\end{tabular}

and Northern Paiute and Mono speakers to its east near Mono Lake and Owens Valley.

These social patterns are mirrored by patterns of bilingualism such as those described by Silver and Miller (1997:86) across Numic language boundaries and between speakers of Northern Paiute and Washo. For example, 10 of the 36 Central Numic speakers surveyed by Miller, Tanner, and Foley (1971) also spoke at least some Northern Paiute. Davis (1965:37) even suggests that Mono Lake Northern Paiute and San Joaquin River Mono are mutually intelligible; given their linguistic differences, it is perhaps more likely that a high level of passive bilingualism was present in the two speech communities. In any case, as we shall show, the social and linguistic profile of the Great Basin has led to significant linguistic diffusion within Western Numic and across the Western-Central Numic boundary.

2.2. Phonology and spelling conventions. If what we call CONSONANT GRADATION is omitted, the Proto-Numic segment inventory is as given in (2), following Iannucci (1973) and Nichols (1974).

(2) Proto-Numic segment inventory (consonant gradation omitted)

(2a) Vowels: $*_{i}, *_{a}, *_{o}, *_{u}, *_{i}$

(2b) Obstruents: *p, *t, *ts, *k, *kw, *?, *s, *h

(2c) Sonorants: $* m, * n, *_{\eta}, *_{w}, *_{y}$

Two points require special discussion. The first concerns the vowel inventory. On the basis of the correspondences in table 1, Iannucci (1973:72-78) and Nichols (1974) reconstruct a sixth Proto-Numic vowel, *ai, which arose in some words from PUA $* a$ and $* i$. Our alternative analysis is that $* a$ and $*_{i}$ remained as such in all Proto-Numic words and then, in Eastern (Central and Southern) Numic, became $* a i$ in some words. ${ }^{14}$ Subsequently, on either analysis, $* a i>e$ in some Central Numic dialects and $* a i>a$ in Colorado River Numic. Kawaiisu shows $a i$ in some words and $a$ in others. One outcome

\footnotetext{
${ }^{14}$ Strictly speaking, Iannucci reconstructs $* e$, not $*$ ai. In any case, the change had various causes; in some words, for example, it was triggered by partial assimilation to the vowel of a neighboring syllable. For details, see Nichols (1974:39-50).
} 
must represent the phonologically regular treatment and the other must reflect diffusion from Central Numic or Colorado River Numic. In Mono (see $\mathbf{5 . 2}$ below), the regular outcome is conservative- $a$ or $i$ as in Northern Paiute-but diffusion from Timbisha has yielded $a i$ or $e$ in some words.

We reject the PN *ai hypothesis for several reasons. When available, UtoAztecan comparative evidence requires reconstructing a vowel that matches the Northern Paiute vowel, either $a$ or $i$. If the change to *ai took place in Proto-Numic, there would be no way to explain its unconditioned split into NP $a$ and $i$, let alone the agreement between Northern Paiute and Uto-Aztecan languages outside Numic. Moreover, since Mono dialects do not agree, one outcome must be analyzed as diffusional in any case. The significance of this point will become clear in $\mathbf{5 . 2}$.

The second point concerns gradation. The three Proto-Numic consonant grades are listed in (3). ${ }^{15}$

(3) Numic consonant grades

(3a) Lenis: $*_{p}, *_{t}, *_{t s}, *_{k}, *^{w}, *_{s}, *_{m}, *_{n}, *_{\eta}, *_{w}, *_{y}$



(3c) Nasal: *mp, *nt, *nts, * $\eta k, *_{\eta} k^{w}, *_{\eta} w, *_{n y}$

The inventories in (3) have some gaps. For example, the laryngeal consonants $* h$ and $* ?$ usually do not enter into the system of gradation. In addition, since no Numic language distinguishes reflexes of fortis vs. nasal grades for the sibilant $*_{s}$, the nasals $*_{m}$, $* n$, and $* \eta$, or the glides $*_{w}$ and $*_{y}$, we assume that Proto-Numic lacked a nasal-grade sibilant, nasal-grade nasals, and fortis glides. ${ }^{16}$ Finally, while we list both $*^{*} k^{w}$ and $*^{*} y w$ in $(3 c)$, there may not in fact have been a contrast between the nasal grades of $* k^{w}$ and $* w$. Note also that although we write as though the nasal-grade stops *mp, etc. were pronounced [mp], etc., it is possible that they were pronounced as [mb], etc.

In most Numic languages, lenis consonants are short and voiced (stops are often spirantized) and fortis consonants are longer, but developments in some languages have affected the structural relations and phonetic realizations of the three grades. In Western Numic languages, for example, as discussed in 3.2.1 below, the Proto-Numic nasal-grade stops became voiced fortis stops with no remaining nasalization (e.g., *puøku > SNP pugg $u$ 'domestic animal, pet').

\footnotetext{
15 Nichols (1974) reconstructs four consonant grades for Proto-Numic, but we accept the arguments of Miller, Elzinga, and McLaughlin (2005) that the four-grade Central Numic system is an innovation vis-à-vis the three-grade Western Numic system.

16 What we reconstruct as $*^{\prime} \eta w$ and $*_{n y}$ become nasals in some languages and glides in some languages (and of course stops in others). Nichols (1974) suggests that Proto-Numic had distinct fortis and nasal-grade nasals which merged in different directions in different languages. Because it is impossible to distinguish the two hypotheses empirically, we have chosen the analysis that posits fewer Proto-Numic segments.
} 
Consonant gradation is of two synchronic types. Within morphemes, the grades simply contrast underlyingly (e.g., PN *mupi 'nose' vs. *timpi 'rock'). Across morpheme boundaries, gradation is triggered by what are usually called FINAL FEATURES. For example, the first-person singular possessive prefix $*_{i}$ - triggers lenis grade in a following consonant (it is said to have a lenis final feature), while the second-person prefix $*_{i}$ - triggers nasal grade (it has a nasal final feature). In Mono Lake Northern Paiute, possessed forms of kuma

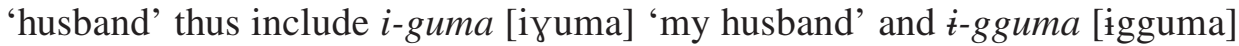
'your husband' (<PN *i-økuma).

Orthographies for Numic languages differ in their spelling of lenis and fortis stops; conventions differ even within the branches, so it can be difficult to interpret forms in isolation. For example, the word pronounced [ti $\beta a$ ] in most Numic languages (PN *tipa 'pine nut') is variously spelled tiva, tiba, or the essentially historical tipa. In a language where lenis [ $\beta]$ is spelled $v$ or $b$, its fortis counterpart is usually spelled $p$, but where $[\beta]$ is spelled $p$, fortis $[\mathrm{p}] \sim[\mathrm{pp}]$ is spelled $p p$. To interpret a $p$ spelling, therefore, one must know the orthographic convention of the language or author in question. For this reason, we normalize spellings. For all Numic languages, we spell fortis stops with double letters ( $p p, t t$, etc.) - they are often described as phonetically long even where they do not contrast with phonetically short voiceless stops-but our spellings of lenis stops vary. In Shoshoni and Timbisha, we follow the standard practice of spelling lenis stops as $p, t$, etc., even if they regularly surface as voiced fricatives; in the other Numic languages, we use the symbols $b$ or $v$ for PN *p; $d$ for PN *t; $g$ or $\gamma$ for PN *k; and so on, in accordance with our sources.

\section{Western Numic.}

3.1. General background. We make reference to the Western Numic dialect areas in (4); see Appendix A for sources and more details, and figure 2 for the places mentioned.

(4) Western Numic dialect areas

(4a) Northern Paiute (NP): Northern Northern Paiute (NNP) Southern Northern Paiute (SNP)

(4b) Mono (Mn):

San Joaquin River Mono (upper San Joaquin River watershed) Kings River Mono (upper Kings River watershed) Northern Owens Valley Mono

Fish Lake Valley Mono

Kaweah River Mono (upper Kaweah River watershed) Southern Owens Valley Mono 
TABLE 2

Western Numic Sound Changes Related to Gradation

\begin{tabular}{|c|c|c|c|c|}
\hline & $\begin{array}{l}* \eta w>* k^{w}\left(>g g^{w}\right) \\
* \text { paywi "fish" }\end{array}$ & $\begin{array}{l}*_{n y}>*_{n t^{y}}\left(>d d^{y}\right) \\
*_{t i h i n y a} \text { 'deer' }\end{array}$ & $* d d^{y}>d d$ & $\begin{array}{c}* D D>T T \\
* t \dot{b} \boldsymbol{b} i \\
\text { 'rock' }\end{array}$ \\
\hline \multicolumn{5}{|l|}{ Northern Paiute } \\
\hline Northern NP & yes $\left(p a \boldsymbol{k} \boldsymbol{k}^{w} i\right)$ & yes $(t \dot{t} h \dot{t} \check{c} \check{c} a)$ & no & yes (tippi) \\
\hline Paradise Valley SNP & yes $\left(p a g g^{w} i\right)$ & yes $(t \dot{t h} \grave{t z} a)$ & no & no $(t \dot{t} \boldsymbol{b} b i)$ \\
\hline Mono Lake SNP & yes $\left(\operatorname{pagg}^{w} i\right)$ & yes $(t i h i d d a)$ & yes & no $(t \dot{t} \boldsymbol{b} \boldsymbol{b} \boldsymbol{i})$ \\
\hline \multicolumn{5}{|l|}{ Mono } \\
\hline San Joaquin River & yes $\left(p a \boldsymbol{k} \boldsymbol{k}^{w} i\right)$ & yes (tihitta) & yes & yes (tippi) \\
\hline Kings River & yes $\left(p a \boldsymbol{k} \boldsymbol{k}^{w} i\right)$ & yes $(t \dot{t} h \dot{t} \check{c} \check{c} a)$ & no & yes $(t i p p i)$ \\
\hline Northern Owens Valley & yes $\left(\operatorname{pagg}^{w} i\right)$ & yes $(t \dot{t h} \dot{t} d d a)$ & yes & no $(t \dot{t} \boldsymbol{b} b i)$ \\
\hline Fish Lake Valley & yes $\left(p a g g^{w} i\right)$ & no (tihinna) & n.a. ${ }^{1}$ & no $(t \dot{t} \boldsymbol{b} b \boldsymbol{b} i)$ \\
\hline \multirow[t]{2}{*}{ Kaweah River } & yes $\left(p a k \boldsymbol{k}^{w} i\right)$ & no $(\operatorname{tihin} a)$ & n.a. & yes (tippi) \\
\hline & $\sim \operatorname{no}\left(p a \eta^{w} i\right)$ & & & \\
\hline Southern Owens Valley & no $\left(p a \boldsymbol{\eta}^{w} i\right)$ & no (tihinna) & n.a. & yes (tippi) \\
\hline
\end{tabular}

We base our Northern Paiute discussion on previous documentation, including descriptions of three northern dialects (Liljeblad 1966, Snapp, Anderson, and Anderson 1982, and Thornes 2003), and our fieldwork on a southern dialect spoken around Mono Lake. ${ }^{17}$ Mono is less well documented despite greater dialect diversity; we base our discussion on descriptions of San Joaquin River and Southern Owens Valley Mono (Lamb 1957 and Norris 1986) and lexical collections by several scholars, especially Lamb's (1954) unpublished survey data. The dialect classification in $(4 b)$ is motivated by patterns discussed below, summarized in table 2. Each dialect area represents the speech of a single watershed or valley in what is generally difficult high-altitude terrain. ${ }^{18}$

A caveat is in order. Because Northern Paiute dialects are better documented than Mono dialects, we can easily map Western Numic phonological and lexical isoglosses, but we cannot fully map morphological and morphosyntactic isoglosses; for most Mono dialects, we have only word lists with

17 This dialect is also spoken in Lee Vining, Bridgeport, and Coleville, California, and in Sweetwater, Nevada. Our consultants are from, or are descended from inhabitants of, Lee Vining, Bridgeport, and Coleville; on the basis of their observations, we include Sweetwater in the same dialect area.

${ }^{18}$ Lamb (1957:14-17) identifies three Mono "superdialects," grouping together Northern Owens Valley and Fish Lake Valley (as "Northeastern" Mono), the San Joaquin River and Kings River watersheds (as "Northwestern" Mono), and the Kaweah River watershed and Southern Owens Valley (as "Southern" Mono). This is geographically plausible, but we are unconvinced that it is justified by isogloss patterns. Norris (1986:34) distinguishes only two dialects, Eastern and Western Mono (divided by the Sierra Nevada crest), but internal differences within each area are significant here. 
minimal grammatical data. In what follows, we take the agreement of available dialect data as evidence for features of a Mono taxon. It remains possible, in particular, that the Northern Owens Valley or Fish Lake Valley dialect will prove to differ from better-documented Mono dialects and will instead turn out to share features with Mono Lake Northern Paiute just to the north. This can be seen in several phonological cases (see 3.2.1 and 7.4 below). If future research identifies similar cases in morphology and morphosyntax, our overall argument that the Mono and Northern Paiute taxa are secondary will only be strengthened.

3.2. Innovations of Western Numic. Western Numic as a taxon is defined by innovations of several types. Some are lexical or quasi-lexical, including the creation of a sound-symbolic alternation between *akka 'red' and *attsa 'tan, brown' (Nichols 1974:260); see 6.1 below. A purely lexical change affected the basic word for 'house': Central and Southern Numic languages retain reflexes of PN *kahni (Ti, WSh, Kw kahni, CR kani), while all Western Numic dialects have nobi. The latter is clearly derived from PN *nopi 'to cover' (or the like), the ancestor of CR novi 'to put bark over' (Kw, CR novi-ppi 'bark covering, windbreak'). ${ }^{19}$ Similarly, in all Western Numic dialects, a new form mu?a has replaced PN *kaku 'mother's mother' (WSh kaku, Kw kagu-, CR kayu-), and the inherited Numic word for '(young) man' has been replaced by *nana, borrowed from Yokuts or another Penutian language of California (Miller 1986:104). This last example may serve to remind us that elements of the lexicon are often considered more liable to diffusion than other aspects of grammar, and less compelling as evidence for subgrouping.

In the next two sections we discuss Western Numic sound changes (3.2.1) and innovations in the morphology of pronouns and demonstratives (3.2.2). Especially interesting, we suggest, are the changes that we do NOT find.

3.2.1. Sound changes. Western Numic as a clade is defined by no phonological innovations. To be sure, there is one sound change with effects throughout Western Numic: the shift of nasal-grade stops to voiced fortis stops (e.g., *mp $>* b b, * \eta k>* g g$ ). This is usually assumed to be a Proto-WesternNumic change (Iannucci 1973:88), since all Western Numic languages either retain the voiced fortis stops as such or, in a further change, have merged them with fortis stops. ${ }^{20}$ The various reflexes are illustrated in (5) for PN *puyku

\footnotetext{
${ }^{19}$ Uto-Aztecan cognates of *kahni include Hopi qeni 'space, room, clear area' (Hopi Dictionary Project 1998:468) and Tb hanii-l 'the house', among others. Even in Western Numic, it survives as SNP kani 'teepee', recorded by Lamb (1954-1955) at Yerington, Bridgeport, and Mono Lake. A nominal use of simplex *nopi is not documented outside Western Numic.

20 The development was presumably $*_{n t}>*_{n d}>d d(>t t)$ or the like. We ourselves have had the experience of mishearing Mono Lake Northern Paiute voiced fortis stops as plain (voiceless) fortis stops; their perceptual similarity presumably lies behind the change. See Babel (2009) for
} 
'horse', in table 2 for PN *timpi 'rock' (CTi, WSh, CR timpi, Cm tipi, Kw timbi), and in table 5 for PN *timpa 'mouth'.

(5) PN *puøku 'domesticated animal'

(5a) Western Numic (*puggu): NNP pukku; SNP puggu; Kings River Mn pukku; Northern Owens Valley Mn puggu; Fish Lake Valley Mn puggu; Kaweah River Mn pukku; Southern Owens Valley Mn pukku (Lamb 1953:segment 27)

(5b) Central and Southern Numic: CTi, WSh, CR punku, Kw pugu-

An argument from relative chronology shows that this change spread across Western Numic after another change had occurred in some but not all dialects. The $* N T>* D D$ change is thus taxon-defining (shared by all Western Numic dialects) but not clade-defining (it was absent in the common ancestor of the Western Numic dialects).

The crucial data concern the development of the Proto-Numic nasal-grade glides $* n y$ and $* \eta w$. In an area of Western Numic, these have become voiced fortis stops $d d^{y}$ and $g g^{w}$ (then merging with fortis stops in some dialects). The data in (6) and (7) show the outcomes of PN *ny throughout Numic. PN *ny became $y$ in Eastern Numic; in Western Numic, it has either retained its nasal component or become voiced fortis $* d d^{y}$ or some further development. Note that the *ny>*ddy change is found in a contiguous area consisting of Northern Paiute and the northwestern Mono dialects. We take this to mean that the change spread areally, rather than occurring independently in the dialects where it occurred, but our analysis does not depend on this inference.

(6) PN *tihinya 'deer'

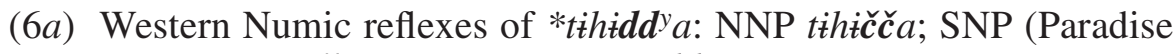
Valley) tìhiža, (Mono Lake) tìhidda; San Joaquin River Mn ṫ̈hitta; Kings River Mn ṫ̈hǐčča (Gayton 1948:258 and Lamb 1954), tihittsa (Lamb 1954); Northern Owens Valley Mn (Benton, Bishop) tìhidda

(6b) Western Numic reflexes of *tihinya: Fish Lake Valley Mn tithinna; Kaweah River Mn tihina; Southern Owens Valley Mn (Fish Springs) tihinna (Lamb 1953:segment 27), (Independence, Lone Pine) tihinna, (Big Pine) tina (Norris 1986:74)

(6c) Central and Southern Numic: CTi, WSh, Cm, Kw tihìy, CR tixiya

(7) PN *pohninya 'skunk'

discussion of the phonetic realization of the voiced fortis and other consonant grades in Mono Lake Northern Paiute. 
(7a) Western Numic reflexes of *pohnidd ${ }^{y} a$ : NNP (Harney Valley) poyičča (Nichols 1974:333); SNP (Paradise Valley) poniža, (Mono Lake) ponidda; San Joaquin River Mn pohitta; Kings River Mn pohičč $a$, pohittsa; Northern Owens Valley Mn (Benton, Bishop) pohidda

(7b) Western Numic reflexes of *pohninya: Fish Lake Valley Mn poninna; Southern Owens Valley Mn (Fish Springs) poninna (Lamb 1953:segment 27), (Fish Springs, Independence, Lone Pine) poninna

(7c) Central and Southern Numic: WTi pohnia-ttsai (Lamb 1954), CTi ponnia-ttsi, WSh pohni?a-ttsi, Cm pohni?a-tsi, Kw pohniya, CR ponniya

The data in (8), (9), and table 2 show the fate of PN * $y w$ in Western and Central Numic. The outcomes are parallel to those of $* n y: g g^{w}$ or its further development in Northern Paiute and contiguous Mono dialects; $\eta^{w}$ in the Kaweah River and Southern Owens Valley Mono dialects (and Timbisha). ${ }^{21}$

(8) PN *paywi 'fish' (Western and Central Numic only)

(8a) Western Numic reflexes of ${ }^{*} p a g g^{w} i$ : NNP (Harney Valley, Warm Springs) pakk $\boldsymbol{k}^{w} i$ SNP (Paradise Valley, Mono Lake) pagg ${ }^{w} i$; San Joaquin River Mn ${\boldsymbol{~} a \boldsymbol{k}^{w}}^{w}$; Kings River Mn $\boldsymbol{a k k}^{w} i$; Northern Owens Valley Mn (Bishop, Benton) pagg $^{w} i$; Fish Lake Valley Mn pagg ${ }^{w} i$; Kaweah River Mn pakk ${ }^{w} i$ (one of two consultants recorded by Lamb 1954)

(8b) Western Numic reflexes of *pay ${ }^{w} i$ : Kaweah River Mn $p a \boldsymbol{y}^{w} i$ (one of two consultants recorded by Lamb 1954), Southern Owens Valley Mn (Fish Springs, Independence, Lone Pine) $p a \boldsymbol{y}^{w} i$

(8c) Central Numic: WTi pay ${ }^{w} i$, CTi pay ${ }^{w} i$, Sh paink ${ }^{w} i$

(9) *notinwa 'wife' (Western Numic only)

(9a) Reflexes of *notigg ${ }^{w} a$ : NNP nodikk ${ }^{w} a$; SNP (Paradise Valley, Yerington, Mono Lake) nodigg ${ }^{w} a$; San Joaquin River Mn nodik $\boldsymbol{k}^{w} a$; Kings River Mn nodik $\boldsymbol{k}^{w} a$; Northern Owens Valley


1989b:409); the latter represents a merger with intervocalic lenis $m$. In Southern Owens Valley Mono, the reflex of nasal-grade $* \eta w>\eta^{w}$ has now merged with the intervocalic reflex of lenis

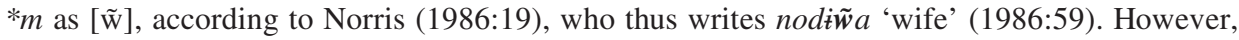
Lamb's (1954) survey data from Independence and Lone Pine in the Southern Owens Valley systematically distinguish $\eta^{w}<*^{*} \eta w$ (e.g., $p a \eta^{w} i$ 'fish') from $\tilde{w}<*_{m}$ (e.g., woosit $\tilde{w} i$ 'four'), and the difference is clearly audible in his field recordings of a speaker from Fish Springs (Lamb 1953-1955:segments 24, 27). We make the distinction in forms we cite.
} 
Mn (Benton) nodigg ${ }^{w} a$; Fish Lake Valley Mn nodigg ${ }^{w} a$ (Steward 1938:304)

(9b) Reflexes of *noti ${ }^{w} a$ : Southern Owens Valley Mn (Independence, Lone Pine) nodì ${ }^{w} a$ (also Steward 1933:300)

The detailed evidence in (5)-(9) is summarized in table 2. What is crucial is that obstruentization $\left(* \eta w>* \eta k^{w}, * n y>* n t^{y}\right)$ did not occur in Southern Owens Valley Mono and affected only $*^{*} y$ in Fish Lake Valley. ${ }^{22}$ Though the $* N T>D D$ change has a broader (pan-Western-Numic) geographic distribution than nasal-grade glide obstruentization (only in Northern Paiute and contiguous Mono dialects), obstruentization fed the $* N T>D D$ change and therefore must have occurred first. For example, the output of obstruentization in *paywi $>$ *payk $k^{w} i$ 'fish' and *tihinya $>* t$ thint $t^{y} a$ 'deer' was then in turn affected by the *NT>DD change, yielding *pagg ${ }^{w} i$ and $* t h i d d^{y} a$. But if the chronologically earlier change was restricted to a subpart of Western Numic, the later change could not have been a Proto-Western-Numic innovation. We conclude that the shift of nasal-grade stops to voiced fortis stops $(* N T>D D)$ was an innovation that diffused across an already differentiated Western Numic dialect network. ${ }^{23}$ We return to the significance of this finding in $\mathbf{8}$ below.

An important isogloss within Northern Paiute dialects, running across $\mathrm{Ne}$ vada, is defined by the treatment of consonant gradation. In what we call Northern Northern Paiute dialects (and independently in most Mono dialects), the Proto-Numic nasal and fortis grades have merged, remaining distinct from lenis consonants. This yields what Thornes (2003) describes as a fortis-lenis contrast. The fortis members of the opposition are generally realized as voiceless stops, while their lenis counterparts are realized as voiced stops or fricatives. The Proto-Numic consonant grades remain distinct, with the nasal-grade series realized as voiced fortis stops, in Southern Northern Paiute dialects and in the neighboring Northern Owens Valley and Fish Lake Valley dialects of Mono. ${ }^{24}$

\footnotetext{
22 Also, crucially, no Western Numic dialect has maintained the nasalization of the original nasal-grade stops. The poorly documented Kaweah River dialect seems to pattern with Southern Owens Valley, but with at least one speaker consulted by Lamb (1954-1955) showing instead a merger pattern more like that of Fish Lake Valley. Note that we symbolize the outputs of the obstruentization change as $* \eta k^{w}$ and $* n t^{y}$. Alternatively, it is possible that these outputs were $* \eta g^{w}$ and $*_{n} d^{y}$ and that the original nasal-grade stops were (or had become) *mb, *nd, etc.

23 An alternative analysis would be that Proto-Numic had fortis glides ${ }^{*} w w$ and $* y y$ rather than nasal-grade glides (so, e.g., *pawwi 'fish', *tihiyya 'deer'), that the shift of nasal-grade stops to voiced fortis stops was a Proto-Western-Numic change, and that the later change was simply glide fortition $\left({ }^{*} w w>g g^{w},{ }^{*} y y>d d^{y}\right)$. Intrinsically, this analysis seems plausible, but it does not explain what would then be the nasal reflexes of $*_{w w}$ and $*_{y y}$ in the Fish Lake Valley, Kaweah River, and Southern Owens Valley Mono dialects. In our analysis, these are archaic.

${ }^{24}$ Iannucci (1973:62) and Nichols (1974:32, n. 3) report that Sven Liljeblad heard voiced fortis stops in the early 1960s in at least some words in Independence, California (Southern Owens
} 
TABLE 3

Selected Numic Demonstratives (Singular Proximal $* i$ - and Distal $* u$-)

\begin{tabular}{|c|c|c|c|c|}
\hline & \multicolumn{2}{|c|}{ Subjective Singular } & \multicolumn{2}{|c|}{ Objective Singular } \\
\hline & Proximal & Distal & Proximal & Distal \\
\hline Proto-Numic & $* i i$ & $* u u$ & $*_{i-k k a}$ & $* u-k k a$ \\
\hline Western Numic & $* i i$ & $* u u$ & $* i-k k a$ & $* u-k k a$ \\
\hline Northern Paiute & $i-s s u$ & $u-s s u$ & $i-k k a$ & $u-k k a$ \\
\hline San Joaquin River Mn & $i-h i$ & $u-h u$ & $i-k k a-h u$ & $u-k k a-h u$ \\
\hline Southern Owens Valley Mn & $i-h h i$ & $u-h h u$ & $i-k k a-h h u$ & $u-k k a-h h u$ \\
\hline Eastern Numic & $*_{i-t i}$ & $* u-t \dot{t}$ & $* i-k k a$ & $* u-k k a$ \\
\hline \multicolumn{5}{|l|}{ Central Timbisha } \\
\hline NEUTRAL & $i-t \dot{t}$ & $u-t \dot{t}$ & $i-k k a$ & $u-k k a$ \\
\hline FOCUS SUBJECT & $i-s \dot{t}$ & $u-s i, u-s u$ & & \\
\hline \multicolumn{5}{|l|}{ Western Shoshoni } \\
\hline NEUTRAL & $i-t \dot{t}$ & $u-t \dot{t}$ & $i-k k a$ & $u-k k a$ \\
\hline FOCUS SUBJECT & $i-s \dot{t}$ & $u-s \dot{t}$ & & \\
\hline Kawaiisu (INANIMATE) & $i-d \dot{t}$ & $u-d \dot{t}$ & $i-k k a-y a$ & $u-k k a-y a$ \\
\hline Colorado Numic (INANIMATE) & $i-\check{c} \dot{t}, i-k k a$ & $u-d u, u-k k^{w} a$ & $i-\check{c} \check{t}-a, i-k k a-y a$ & $u-d u-a, u-k k^{w} a-y a$ \\
\hline
\end{tabular}

3.2.2. Changes in pronouns and demonstratives. Changes in the Western Numic system of pronouns and demonstratives warrant a special discussion. In this context, "pronouns" are forms with first- or second-person reference and "demonstratives" have third-person reference; all Numic demonstrative systems also contrast multiple degrees of deixis.

If plurals, possessives, and some other complications are ignored, most non-clitic demonstratives in Numic languages have at least two components: a deictic base and a subjective or objective suffix. Table 3 illustrates the formation of singular subjective and objective demonstratives from the deictic bases $* i$ - and $* u$-, whose reflexes are often described as proximal and distal respectively. No language has a system with only these two deictic bases, but the changes of interest here concern suffixes. ${ }^{25}$ The reconstructions in table 3 are ours.

Valley). Lamb's (1954) survey data for Independence consistently show merger of the fortis and voiced fortis consonant grades. Our "Northern" and "Southern" Northern Paiute dialects match Liljeblad's (1966) "northern" and "southern" dialects. They are not equivalent to what Nichols (1974) calls "Oregon" and "Nevada" Northern Paiute respectively, since a subset of the latter have merged the Numic fortis and voiced fortis consonant grades. Neither Liljebad nor Nichols explicitly identifies the features distinguishing the two dialect groups they identify.

${ }^{25}$ Distal * $u$ - is glossed 'invisible' or 'out of sight' in languages with elaborate systems. Western Numic languages and Kawaiisu have three degrees of deixis (the third base is "medial," "neutral," or "topical" $m a$-); Colorado River Numic has four (the fourth base is $a$-); and Central Numic languages have six (the fifth and sixth bases are $a i-\sim e$ - and $o$-). We assume that Proto-Numic had a three-way system and that Central Numic and Colorado River Numic 
The reconstruction of objective $* i-k k a, * u-k k a$ is unproblematic. These occur throughout Numic, extended in Colorado River Numic by an objective ending - $(y) a$ and in Mono by a suffix - $h h u$. The latter is also one of three suffixes typical of subjective singular demonstratives: -ssu in Northern Paiute, $-h h u$ in Mono, and *-tit throughout Central and Southern Numic. All three of these suffixes, we suggest, arose through the grammaticalization of forms whose existence is independently supported.

The source of NP -ssu is an enclitic *-ssu documented as such in Colorado River Numic, where it is glossed 'also, again, same; just, only' and is regularly added to demonstratives (Sapir 1930:95-96, 177-78). ${ }^{26}$ From this starting point, the first stage of grammaticalization is preserved in Central Numic, where $-s \dot{t}$ or $-s u$ appears on the "focus subject" pronouns in table 3. These forms are used as subjects only (Dayley 1989b:143-45 and Miller 1996:705) in sentences like those in (10). The Timbisha deictic base $e$ - in (10a) refers to location "nearby but not right here."

(10) Central Numic focus subject $-s \dot{t},-s u$

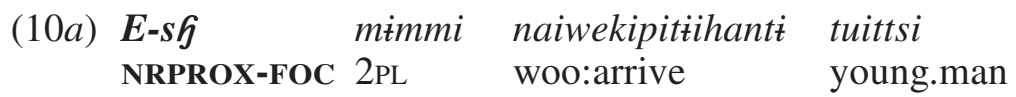

'This is the one who is coming to woo you all, the young man'. (Dayley 1989b:144)

Central Timbisha

(10b) U-su ha kahni?

DIST-FOC Q house

'Is that a house?' (Dayley 1989b:145) Central Timbisha

(10c) $\boldsymbol{U}$-sgn tsa?u tegk ${ }^{w} a p p \dot{t}$ nit wikkumpahkantuPih PROX-FOC certainly man 1SG kill:will

'It's for sure that the man will kill me'. (Miller 1996:705)

Western Shoshoni



'She is my best friend'. (Crum and Dayley 1993:30)

Western Shoshoni

Crum and Dayley (1993:29) and Gould and Loether (2002:49) call these "contrastive/presentative." They do not occupy the same positions in their

have elaborated. In Central Numic and Kawaiisu, there is a further contrast between definite and indefinite (Zigmond, Booth, and Munro 1990:46) or "obviative" and "proximate" (Dayley 1989b:135-36 and Crum and Dayley 1993:25-26) demonstratives.

${ }^{26}$ It is presumably related to the $s$-initial base of the Central Numic and Kawaiisu proximate or definite forms mentioned in n. 25, e.g., CTi $s$ - $i-t \dot{t}$ 'this (one) right here', $s-u$ - $t \dot{t}$ 'that (one) not visible' (Dayley 1989b:137). 
demonstrative systems as NP $i$-ssu, etc., since the Central Numic paradigms contrast subjective $*_{-t} t \dot{t}$ and objective $*_{-k k a}$; the focus subject forms lie outside this paradigm. Based on a pattern like that of Central Numic, Northern Paiute has innovated by fully incorporating its -ssu forms into the demonstrative paradigm as the ordinary subjective singular forms.

Singular subjective $*_{-t} t \dot{\text { is }}$ found throughout Central and Southern Numic. This probably arose as a specialization of the suffix whose other conspicuous reflexes are the pan-Numic nominalizer *-ti (studied in detail by Toosarvandani 2010) and the postpositional formative *-ti described in Central Numic as a "postposition adjunct" (Dayley 1989b:202, Crum and Dayley 1993:79, and Gould and Loether 2002:81) and in Northern Paiute as a "general essive" postposition 'to, at, right there' (Liljeblad 1966 and Thornes 2003:229). We suggest that the Eastern Numic demonstratives in $*_{-} t \dot{t}$ were originally $*_{i-t} \dot{t}$ 'here, at this place', *u-tit 'there, at that place', etc. Comparable Western Numic formations on the margins of the demonstrative system include NP ma-ttG- $u$ 'here' (Liljeblad 1966) and Southern Owens Valley Mn aa-ttG- $u$ 'the one over there' (Norris 1986:56) from the deictic base ma-, aa- 'there', and a distal suffix $-u$. As their originally explicitly locational meanings were attenuated, forms like $* i-t \dot{t}$ were incorporated into the Central Numic demonstrative system sensu stricto as neutral subjective forms.

The Mono demonstrative suffix $-h u$ or $-h i$, unlike NP $-s i$ and Central Numic $*-t \dot{t}$, is found on both subjective and objective forms. We follow Norris (1986:106) in accepting a connection to the Numic indefinites in $h$-. In particular, we propose that the Mono suffix originated as an enclitic version of the root of Southern Owens Valley Mn hii 'what' (subjective), hima 'what' (objective). Subjective hii has a Northern Paiute cognate hii 'thing, whatchamacallit' (Thornes 2003:188), with comparable forms in Central and Southern Numic. We suggest that the Mono demonstratives are in effect etymologically 'this thing', 'that thing', etc., an analysis that explains the observation of Norris (1986:106) that these forms "are pronouns, and have no attributive function." 27

We conclude that the three Numic subjective singular demonstrative types (Eastern Numic $* i$-tit, Mn $i$-hi, NP $i$-ssu, etc.) were independently formed from unsuffixed demonstratives of the type $* i i$, *uu, etc., and we reconstruct these for Proto-Numic. It is of special interest that Mono and Northern Paiute underwent significant innovations, creating new subjective demonstrative forms, but the original Western Numic system showed no innovations visà-vis Proto-Numic.

\footnotetext{
27 We have no account of the vocalism of the Mono suffix unless the synchronically basic variant $-h u$ originally resulted from assimilation to the deictic base $u$ - and was then generalized for some reason. Jane Hill points out to us that O'odham has a suffix - $h u$ on locatives that are very distant, out of sight, or of indeterminate location.
} 
TABLE 4

Numic Subjective (and Objective) Pronouns

\begin{tabular}{|c|c|c|c|c|c|c|}
\hline & $1 \mathrm{sg}$ & $2 \mathrm{SG}$ & INCL DL & INCL PL & EXCL PL & $2 \mathrm{PL}$ \\
\hline $\begin{array}{l}\text { Proto-Numic } \\
\text { Western Numic }\end{array}$ & $* n \dot{t}$ & $*_{i}$ & $* t a$ & $* t a-\eta w a$ & $* n \dot{t}-m m \dot{t}$ & $*_{\dot{t}-m m \dot{t}}$ \\
\hline $\begin{array}{l}\text { Northern Paiute } \\
\text { (OBJECTIVE) }\end{array}$ & $\begin{array}{l}n \dot{t} \\
(n \dot{t} k k a)\end{array}$ & $\begin{array}{l}\dot{t} \\
(\dot{t} m i)\end{array}$ & $\begin{array}{l}\text { ta } \\
(\text { takka })\end{array}$ & $\begin{array}{l}\text { tammi } \\
(\text { tammikka) }\end{array}$ & $\begin{array}{l}\text { nimmi } \\
(\text { nimmikka) }\end{array}$ & $\begin{array}{l}\dot{t} m m \dot{t} \\
(\text { ummi) }\end{array}$ \\
\hline San Joaquin & & & & & & \\
\hline $\begin{array}{l}\text { River Mn } \\
\text { (OBJECTIVE) }\end{array}$ & $\begin{array}{l}n \ddot{i t} \\
\text { (niwikka) }\end{array}$ & $\begin{array}{l}\ddot{i} \\
(\dot{i m m i k k a})\end{array}$ & $\begin{array}{l}\text { ta } \\
(\text { tamikka) }\end{array}$ & $\begin{array}{l}\operatorname{taaqq}^{w} a \\
(\text { taimmikka) }\end{array}$ & $\begin{array}{l}n \ddot{t} \dot{t} q q^{w} a \\
(\text { niimmikka) }\end{array}$ & $\begin{array}{l}\ddot{i t q q} q^{w} a \\
(i i m m i k k a)\end{array}$ \\
\hline N Owens & & & & & & \\
\hline $\begin{array}{l}\text { Valley Mn } \\
\text { S Owens }\end{array}$ & $n \ddot{t} \dot{t}$ & & taa & $\operatorname{taagg}^{w} a$ & & $\ddot{i t g} g^{w} a$ \\
\hline $\begin{array}{l}\text { Valley Mn } \\
\text { (OBJECTIVE) }\end{array}$ & $\begin{array}{l}n \ddot{t} \\
(n \dot{t} k k a)\end{array}$ & $\begin{array}{l}\ddot{i t} \\
(\dot{i} m i k k a)\end{array}$ & $\begin{array}{l}\text { taa } \\
(\text { tamikka) }\end{array}$ & $\begin{array}{l}\operatorname{taa\eta }^{w} a \\
(\text { tamimmikka) }\end{array}$ & $\begin{array}{l}n \ddot{t} \eta^{w} a \\
(\text { nimimmikka) }\end{array}$ & $\begin{array}{l}\dot{t} \eta^{w} a \\
(\dot{t} m i m m i k k a)\end{array}$ \\
\hline Eastern Numic & & & & & & \\
\hline $\begin{array}{l}\text { Central Timbisha } \\
\text { (oBJective) }\end{array}$ & $\begin{array}{l}n \dot{t}, n \ddot{t} \\
(n \dot{t}, n i a)\end{array}$ & $\begin{array}{l}\dot{t}, \ddot{t} \dot{t} \\
(\dot{t}, \dot{t} m m i)\end{array}$ & $\begin{array}{l}\text { tayku } \\
(\text { tahi, tahu-) }\end{array}$ & $\begin{array}{l}\text { tammi } \\
(\text { tammi })\end{array}$ & $\begin{array}{l}\text { nimmit } \\
(\text { nimmi) }\end{array}$ & $\begin{array}{l}\text { mimmi } \\
(\text { mimmi) }\end{array}$ \\
\hline $\begin{array}{l}\text { Western Shoshoni } \\
\text { (OBJECTIVE) }\end{array}$ & $\begin{array}{l}n \dot{t} \\
(n \dot{i} i)\end{array}$ & $\begin{array}{l}\dot{t} \\
(\dot{t} m m i)\end{array}$ & $\begin{array}{l}\text { tawi } \\
(\text { tahi) }\end{array}$ & $\begin{array}{l}\text { tammi } \\
(\text { tammi })\end{array}$ & $\begin{array}{l}\text { nimmi } \\
(\text { nimmi) }\end{array}$ & $\begin{array}{l}\text { mimmi } \\
(\text { mimmi) }\end{array}$ \\
\hline Comanche & $n \ddot{t} \dot{t}$ & $\dot{t} n \dot{t}, n \ddot{t} \dot{t}$ & ta, tahi & tanni & ninnt & minni, mimmí \\
\hline $\begin{array}{l}\text { Colorado River } \\
\text { (oBJECTIVE) }\end{array}$ & $\begin{array}{l}n \dot{t} \\
(\text { ninnia) }\end{array}$ & $\begin{array}{l}\text { immi } \\
(\text { immia })\end{array}$ & $\begin{array}{l}\text { tammi } \\
\text { (tammia) }\end{array}$ & $\begin{array}{l}\operatorname{ta\eta }^{w} a \\
\left(\operatorname{ta\eta }^{w} a y a\right)\end{array}$ & $\begin{array}{l}\operatorname{nimm}^{w} i \\
\left(\text { nimm }^{w} i a\right)\end{array}$ & $\begin{array}{l}m^{w} \dot{t} m m^{w} i \\
\left(m^{w} \dot{t} m m^{w} i a\right)\end{array}$ \\
\hline
\end{tabular}

Turning now to the pronominal system, we do find at least two Western Numic innovations. One is the creation of a first-person singular possessive proclitic $i$, documented in Mono dialects (Lamb 1957:176-79 and Norris 1986:129) and Northern Paiute (Liljeblad 1966, Snapp, Anderson, and Anderson 1982:38, and Thornes 2003:157, 168). Other Numic languages do not share this form (e.g., Shoshoni has $n i$ in the same function), and Nichols (1974:223) suggests that Western Numic has innovated by extending a proximal demonstrative root to first-person singular pronominal function. ${ }^{28}$

Western Numic is also defined by changes in the pronominal system. Table 4 shows subjective and objective pronouns in various Numic languages. ${ }^{29} \mathrm{We}$ see first that the objective suffix $*_{-k a}$, found across Numic in the demonstrative paradigms in table 3 , is used with first- and second-person pronouns only in Mono and Northern Paiute. In Central and Southern Numic, by contrast,

28 As Nichols observes, a similar, apparently independent, change has also occurred in Hopi.

${ }^{29}$ Central Numic exclusive and second-person duals are omitted. Norris (1986:127) cites the


1953:segment 32), they clearly have $\left[\eta^{\mathrm{w}}\right]$ not $[\tilde{\mathrm{w}}]$. Recall that present-day $[\tilde{\mathrm{w}}]$ reflects the merger of earlier $\eta^{w}<* \eta w$ and $\tilde{w}<$ lenis $* m$. 
objective *-ka occurs only in the demonstrative system but not on pronouns. Pronominal objective $*_{-} k a$ is evidently a Western Numic innovation.

The Mono and Northern Paiute plural subjective paradigms conspicuously differ. We assume that alternating paradigms are likelier to be archaic, while regular paradigms are often the result of leveling; and based on Colorado River Numic, we therefore reconstruct a plural inclusive ending $*_{-} \eta w a$ and an ending $*_{-}-m m \dot{t}$ for the other plurals. ${ }^{30}$ The inclusive plural stands out in having a dual base *ta (the other plural forms are based on singulars) and a different ending from the other forms. All Western and Central Numic languages have leveled this alternating pattern. Mono extended the $*_{-} \eta w a$ ending from the plural inclusive to the exclusive and second-person plurals; Northern Paiute generalized -mmi (replacing PN *-mmi) from the exclusive to the inclusive; and Central Numic generalized exclusive and 2PL - $m m i$. The result is a different uniform pattern in each language.

What is most interesting overall is that the reconstructible system of Western Numic pronouns and demonstratives does not differ significantly from that of Proto-Numic. The most significant Western Numic structural innovations (in the subjective singular demonstratives and the subjective plural pronouns) are actually changes where Mono and Northern Paiute diverge, each transforming the original state of affairs in some distinctive way. By contrast, the Eastern Numic languages agree in having innovated subjective singular demonstratives in $*$ - $t \dot{t}$.

3.2.3. Summary. We have found that while the Western Numic languages do show a few significant phonological and morphological innovations vis-à-vis Proto-Numic, they were not Proto-Western-Numic changes (even assuming that Western Numic is a true clade). Some were innovations postdating Proto-Western-Numic; others were isolated developments of particular Western Numic dialects. Lexical innovations are among the clearest sources of evidence for Western Numic.

4. Methodology. In 5 and $\mathbf{6}$ below, we assess the evidence for Mono and Northern Paiute as clades. If they are indeed clades, it should be

30 These endings were underlyingly /-wa/ and /-mi/, with fortis or nasal-grade consonants conditioned by the roots to which they were added. (Recall that fortis and nasal grades do not contrast for glides or nasals.) In the inclusive and exclusive plurals, the NP $i$ vocalism instead of original $\dot{i}$ is due to the objective forms, where $i$ is pan-Numic; tammi, nimmi were leveled from tammikka, nimmikka.

Our account differs from the analyses of Sapir (1930:178), Nichols (1974:201-26), and Norris (1986:194-202), all of whom assume in one way or the other that the inclusive plural ending had the same consonant as the other plural endings. But a correspondence involving San Joaquin River Mn $*_{-} k k^{w} a$, Northern Owens Valley Mn $-g g^{w} a$, and Southern Owens Valley $M n-\eta^{w} a$ can be explained only by assuming original *- $\eta w a$, which can also explain CR taywa. (Sapir, of course, did not know the Mono data.) The replacement of PN 2PL $* i$-mmi with a new form based on a $2 \mathrm{DL}$ root $* m \dot{t}$ (WSh $m \dot{w} w \dot{t}, \mathrm{Cm} m \dot{m}$ ) was an Eastern Numic innovation. 
possible to identify the innovations of their respective ancestors. Our procedure has been to study published dictionaries and grammatical descriptions, and unpublished sources available to us, to find features shared by all Mono dialects or all Northern Paiute dialects; we examined comparative data to determine whether such features are innovations or archaisms. We studied lexical data, comparative phonology, all areas of morphology, and areas of morphosyntax where we found useful data; we tried to be exhaustive, but of course it is possible that we missed some innovations common to either the Mono dialects or the Northern Paiute dialects.

Before proceeding, we note a recurrent analytic problem. For many of the linguistic features we discuss in this paper, if the distribution of some innovation does not correspond to a plausible clade, it is reasonable to ask if the diffusional analysis we propose is the only good alternative. In some cases, it may instead be possible to posit parallel independent development or "drift." We address this question in $\mathbf{8}$ for phonological innovations in particular; more generally, we can say here that geography provides the best way to distinguish diffusion from drift. If innovations tend to cluster geographically in contiguous areas, they are less likely to be independent and more likely to be diffused. By and large, the patterns we examine here do cluster in this way-for example, innovations of Mono and its Central Numic neighbor Timbisha - but we cannot exclude the possibility that some individual cases that we interpret as diffusion are in fact due to drift. ${ }^{31}$

5. Mono innovations. In this section, we evaluate the evidence for a Mono clade. As we shall show, innovations limited to Mono dialects are significantly less numerous than those shared with Central Numic languages, especially Timbisha.

5.1. Innovations limited to Mono. We have found only three unique Mono innovations. Two affect demonstrative and pronoun paradigms and were discussed in 3.2.2. The first of these, illustrated in table 3, is the grammaticalization of the formative $-h u$ or $-h i$ as a demonstrative suffix. The other is the extension of the plural inclusive ending $*_{-} \eta w a$ to the exclusive and second-person plural forms, illustrated in table 4.

A third Mono innovation is the creation of a verbal suffix -ppa?i, which in both well-described dialects is said to express repeated action (Lamb 1957:268 and Norris 1986:150). Central Numic languages have a suffix -Pi that marks verbal plurality; it is surely related to the Mono suffix, but a combination

\footnotetext{
${ }^{31}$ It is worth adding that cases of drift would also serve our broader argument. For instance, if Mono and Timbisha share some innovation due to drift rather than diffusion, then the innovation must be trivial enough (for a Numic language) that its presence in all Mono dialects is not necessarily good evidence for a Mono clade.
} 
with - ppa does not occur outside of Mono and is clearly an innovation. For further discussion of verbal plurality, see $\mathbf{7 . 1}$ below.

5.2. Innovations shared with Timbisha. In contrast to the small number of innovations found only in Mono dialects, a relatively large number of innovations are shared by Mono dialects with other Numic languages but not with Northern Paiute. Some of these are restricted to Mono and Timbisha; others are found throughout Central (and sometimes also Southern) Numic.

5.2.1. Innovations limited to Mono and Timbisha. Mono and Timbisha share two morphological innovations. First, in the productive derivation of habitual agent nominals from verbs, the two languages use the same suffix -tti. For instance, CTi nikka-ttg 'dancer' (nikka 'dance') refers to the characteristic agent of dancing; San Joaquin River Mn tiboo-tt5'haircutter' (tiboo 'cut hair') refers to the typical agent of hair cutting. This suffix occurs nowhere else in Numic with this function and form. Toosarvandani (2010) argues that it arose as a special use of the Numic subject nominalizer *-ti (e.g., San Joaquin River Mn tikka-dit 'one who is eating, one who ate'), which, unlike habitual agent $-t t i$, ordinarily does not have a fortis consonant.

Second, Mono and Timbisha share an objective case suffix - $n a$. This appears nowhere else in Numic. Norris (1986:181-85) makes the plausible proposal that it arose through reanalysis of the widely attested objective case suffix $-a$ and a preceding nasal final feature. ${ }^{32}$ The most straightforward interpretation of this distribution is that -na is a feature diffused across the Western-Central Numic language boundary between Mono and Timbisha. The analysis is complicated somewhat by the fact that all suffixal case marking on nouns has been lost in Northern Paiute (in both Western Numic languages, $-k a$ is restricted to the pronominal paradigm). Instead, as we discuss in 6.1, an objective proclitic $k a=$ has been innovated through grammaticalization of the demonstrative pronoun ika (Nichols 1974:216-17). Because of this dramatic revision of the Northern Paiute case inventory, it is conceivable that - $n a$ diffused throughout all of Western Numic before being supplanted by $k a=$ in Northern Paiute. In either scenario, an essential step in the evolution of this isogloss dividing the two Western Numic languages is the spread of an innovation through (at least) the Mono and Timbisha speech communities.

5.2.2. Innovations shared with Central Numic. Several changes shared by Mono and Timbisha are more widely distributed in Central (and sometimes Southern) Numic. The first concerns the word for 'mountain', Mn toya-bi

\footnotetext{
32 The distribution of -na differs in the two languages. In Southern Owens Valley Mono, it occurs only on nouns bearing a fortis final feature that corresponds regularly to a nasal final feature in Shoshoni dialects, while in Central Timbisha, it occurs on nouns with no other objective suffix or ones that take $-i$. San Joaquin River Mono has generalized -na to all nouns ending in a vowel (i.e., all of them except those ending in a glottal stop).
} 
vs. NP kai-ba (the final morphemes are absolutive suffixes). The former is attested in all Mono dialects, with cognates of the form *toya-pi throughout Central Numic, including Timbisha. The Northern Paiute form (PN *kawi-pa) is shared with Southern Numic (Kw kee-vi, CR kaiva). The latter is clearly archaic, as shown both by its discontinuous geographic distribution within Numic and by cognates elsewhere in Uto-Aztecan (see 22a). The variant found in Mono and Central Numic is not found elsewhere and must be an innovation. ${ }^{33}$

Further lexical evidence for diffusion between Mono and Central Numic comes from three words in which PN *a was replaced by *ai, possibly in anticipation of a high vowel in the following syllable. The relevant data are shown in (11)-(13). As indicated in $\mathbf{2 . 2}$ above, our analysis is that the $* a \rightarrow$ *ai replacement in these words was an Eastern Numic innovation that has diffused into Mono. In some languages, $* a i>e$; and in Colorado River Numic, compensatory palatalization arose when $* a i>* a .{ }^{34}$

(11) PN *ati 'bow' (later also 'gun')

(11a) Comparative evidence: Tb aali- $t<* a-t i-;$ cf. Classical Nahuatl atlatl 'atlatl' $<* a-t a-$

(11b) *a: NP $\boldsymbol{a} d \dot{t}$

(11c) *ai: San Joaquin River Mn edi, WTi aiti, CTi $\boldsymbol{e} t \dot{t} \sim a i t \dot{t}$, WSh aiti, $\mathrm{Cm} \boldsymbol{e} e t \dot{t}$, Kw $\boldsymbol{e} d \dot{t}$

(11d) $* a i>* a$ (with following consonant palatalization): CR $a \check{a} \grave{t}$

(12) PN *pati 'daughter' (attested in Numic only)

(12a) *a: NP padi

(12b) *ai: San Joaquin River Mn pedit, Northern Owens Valley Mn (Benton) pedi, Southern Owens Valley Mn paidi (Steward 1933:299), ${ }^{35}$ WTi paitsi, CTi peti $\sim$ paiti, WSh paiti, Cm peti, $\mathrm{Kw}$ pedi-

(12c) $* a i>* a$ (with following consonant palatalization): CR pač

(13) *akki- 'acorn mush' (attested in Western Numic only)

33 Though, of course, there are exceptions, it is well established in dialectology (Chambers and Trudgill 1980:183-84) that older features often have a discontinuous or peripheral distribution, while innovations spread continuously from their point of origin. As noted by an IJAL reviewer, PN *kawi- may have a Central Numic reflex in Sh koi ko'i 'peak, summit, heap, mound'.

${ }^{34}$ Since *akki- 'acorn mush' in (13) is attested only in Western Numic, either the form with $* a i$ originated in an unattested Eastern Numic cognate or the $* a \rightarrow * a i$ change was generalized as such in Mono. Note that we reserve the headless arrow $(>)$ for regular sound changes and use an ordinary arrow $(\rightarrow$ ) for lexically sporadic replacements and morphological changes.

35 Steward cites this form from "Owens Valley." This usually signifies a speaker from Big Pine or Lone Pine in Southern Owens Valley. We likewise assume a Southern Owens Valley source for the form $i b i$ in $(15 a)$. 
TABLE 5

Proto-Numic Absolutive *-pa

\begin{tabular}{|c|c|c|c|c|}
\hline & $\begin{array}{l}\text { 'face' } \\
\text { *ko-pa }\end{array}$ & $\begin{array}{l}\text { 'mouth' } \\
* t \dot{t}-\mathbf{m p a}\end{array}$ & $\begin{array}{l}\text { 'sun' } \\
* \text { ta-pa }\end{array}$ & $\begin{array}{l}\text { 'wind' } \\
\text { *hinwa-ppa }\end{array}$ \\
\hline Northern NP & $k o-b a$ & $t \dot{t}-p p a$ & $t a-b a$ & $h i k k^{w} a-b a$ \\
\hline Southern SP & $k o-b a$ & $t \dot{t}-b b a$ & ta-ba & higgwa-ppa \\
\hline San Joaquin River Mn & qo-be & $\begin{array}{l}\text { ti-ppe (Northfork), } \\
t \dot{t}-p p \dot{i} \text { (Auberry) }\end{array}$ & tabe-, tada-be & $h \dot{k} k k^{w} a-p p e$ \\
\hline Kings River Mn & & $t \dot{t}$-ppe & tada-be & $\begin{array}{l}h \dot{i} k k^{w} a-p p e, \\
h \dot{t} k k^{w} a-p p \dot{\boldsymbol{t}}\end{array}$ \\
\hline $\begin{array}{c}\text { Northern Owens } \\
\text { Valley Mn }\end{array}$ & ko-be & ti-bbe & & \\
\hline Fish Lake Valley Mn & & ti-bbe & tada-be (Gavton & $h_{i g g^{w} a-p p a}$ \\
\hline Kaweah River Mn & & ti-ppe & $1948: 229)$ & \\
\hline $\begin{array}{c}\text { Southern Owens } \\
\text { Valley Mn }\end{array}$ & & $t \dot{t}-p p a$ & $\begin{array}{l}\text { ta-be (Independence), } \\
\text { ta-bai (Lone Pine) }\end{array}$ & $\begin{array}{l}h \dot{i} \eta^{w} a-p p a \\
h \dot{i} \eta^{w} a-p p \dot{i}\end{array}$ \\
\hline Central Timbisha & ko-pe & ti-mpe & ta-pe & \\
\hline Western Shoshoni & ko-pai & $t \dot{t}-m p a i$ & ta-pai & \\
\hline Kawaiisu & kovi- & $t \dot{t}-m b i-v \dot{t}$ & $t a-v i$ & \\
\hline Colorado River Numic & kova & timpa & tava & \\
\hline
\end{tabular}

(13a) *a: SNP akki-bba

(13b) *ai: San Joaquin River Mn $\boldsymbol{e} k k i-b e$, Kings River Mn $\boldsymbol{e} k k i-b i$, Northern Owens Valley Mn $\boldsymbol{e} k k i$-be, Southern Owens Valley Mn ekki-bi (Norris 1986:100)

In a similar change, $\mathrm{PN} * i$ was replaced by $* a i$ in the related forms in (14)

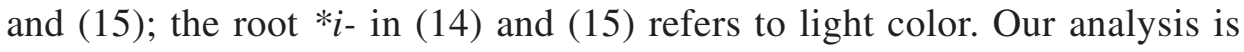
again that the change to *ai was an Eastern Numic innovation, which then diffused into Mono, and that $* a i>a$ in Colorado River Numic.

(14) $\mathrm{PN} * i-s i$ 'gray'

(14a) *i: NNP isi-, SNP (Mono Lake) isi-

(14b) *ai: San Joaquin River Mn esi-, Northern Owens Valley Mn (Bishop) asi (Steward 1933:331), CTi esti-, WSh aist-, Cm esi-

(15) PN *i-pi 'white paint, chalk' (absolutive suffix -pi)

(15a) *i: NNP ibi, SNP (Mono Lake) ibi, Southern Owens Valley Mn ibi (Steward 1933:277)

(15b) *ai: San Joaquin River Mn $\boldsymbol{e b i}$; Kings River Mn ebi (Gayton 1948:265); CTi aipi, epi; WSh aipi

(15c) *ai $>* a$ : Kw $\boldsymbol{a} v i$ 
A final shared feature of Mono and Timbisha concerns the absolutive suffixes that appear on nouns in Numic (and Uto-Aztecan generally) when neither possessed nor part of a compound. Table 5 shows four cognate sets with an absolutive suffix $*$ - $p a$ or its successor in various languages. ${ }^{36} \mathrm{PN} *$ - $p a$ is preserved in Northern Paiute but was replaced by $*_{-}$pai in Central and Southern Numic, no doubt due to the $* a \rightarrow * a i$ change in (11)-(13) above. ${ }^{37}$ Subsequently, *-pai >-pe in Timbisha; this form of the suffix has diffused into Mono dialects. In Kawaiisu, *-pai was replaced by another absolutive suffix, $*_{\text {-p }} i>-v i$, and $* a i>a$ regularly in Colorado River Numic. So, for example, PN *ko-pa 'face' (NP ko-ba) was replaced by *ko-pai (WSh ko-pai) > CR kova, Ti ko-pe, also diffusing into Mono dialects as ko-be.

5.3. Summary. Innovations uniquely shared by all Mono dialects are not numerous in comparison to those shared by Mono and Timbisha (or Central Numic generally). It makes most sense to interpret them not as clade-defining but as a special case of a broader pattern whereby innovations in the southwestern area of Western and Central Numic diffuse areally, even across dialect boundaries. If so, the bundle of innovations defining Mono is largely an effect of diffusion.

6. Northern Paiute innovations. In this section, we show that while Northern Paiute does have a number of unique innovations (6.1), there is also a pattern of areal diffusion like that seen in 5: changes shared by Northern Paiute dialects and neighboring Shoshoni dialects (6.2).

6.1. Innovations limited to Northern Paiute. Several distinctive innovations are shared by all dialects of Northern Paiute and appear nowhere else in Numic. One we have already discussed (in 3.2.2): the creation of subjective singular demonstratives in -ssu, illustrated in table 3. A second is found in the color terms, formed in Northern Paiute with a suffix combination reflecting earlier $*_{-} g g^{w} i-d d^{y} a<\mathrm{PN} *_{-} \eta w i-n y a$. Examples include

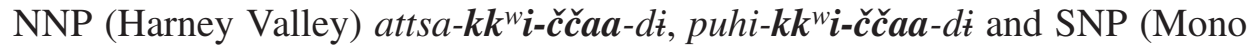
Lake) attsa-gg ${ }^{w} \boldsymbol{i}$-ddaa-di, pu?i-gg ${ }^{w} \boldsymbol{i}$-dda $\boldsymbol{a}$-dit for 'red' and 'blue-green' respectively. Elsewhere in Numic, including Mono and Central Numic, color terms are formed with different suffixes or suffix combinations. For example, terms for 'red' based on PN *ayka- *akka- include San Joaquin River Mn aqqa-banagi, Kings River Mn, Northern Owens Valley Mn akka-banagi-di,

\footnotetext{
${ }^{36}$ Empty cells represent attestation gaps. Suffix gradation is typically conditioned by final features of roots and sometimes shifts (e.g., *-ppa in 'wind' vs. *-pa > NNP -ba). Norris (1986: 175-76) observes that *-pa is sometimes replaced by *-pi in Southern Owens Valley Mono; cf. innovative hit $\eta^{w} a-p p \dot{t}$ 'wind' (Norris 1986:175) vs. conservative hỉw a-ppa (Lamb 1954).

37 These related changes appear to be Eastern Numic innovations; as such, they are further evidence for the analysis of Freeze and Iannucci (1979) mentioned in $\mathbf{2 . 1}$ above.
} 
TABLE 6

Proto-Numic Postural Verbs

\begin{tabular}{|c|c|c|c|c|c|c|}
\hline & & Mono & NNP & CTi & WSh & $\mathrm{CR}$ \\
\hline \multirow[t]{3}{*}{ 'sit' } & SG & katti & katti & kati & kati & kadi \\
\hline & DL & $y \dot{t} k k^{w} i$ & $y \dot{t} g^{w} i$ & $k a t \dot{t}, y \dot{t} k^{w} i$ & $y \dot{t} k^{w} i$ & kadi \\
\hline & PL & $y \dot{i} k k^{w} i$ & aatta?a & nиираi, уиипаа & $y i k^{w} i$ & $y u \gamma^{w} i$ \\
\hline \multirow[t]{3}{*}{ 'stand' } & SG & wint & wint & wint & wint & winni \\
\hline & DL & kono & wami & wiwint & tsatsakki & winni \\
\hline & PL & kono & kono & toppayi, tattsaho & topo?i & $w a \eta^{w} i$ \\
\hline \multirow[t]{3}{*}{ 'lie' } & SG & habi & happi & hapi & hapi & $a v i$ \\
\hline & DL & $k^{w} a b i$ & $k^{w} a p p i$ & $k^{w}$ opi, kopi & $k^{w} a p i$ & $a v i$ \\
\hline & PL & $k^{w} a b i$ & $\operatorname{pokk}^{w} a$ & kopi-ttiki & $k^{w} a p i$ & $k^{w} a v i$ \\
\hline
\end{tabular}

Southern Owens Valley Mn aqa-hani (Lamb 1953:segment 29), CTi aøkapiti, and WSh aigka-pihti. ${ }^{38}$

A third Northern Paiute innovation is found in paradigms of verbs that distinguish number. All Numic languages have such verbs; they include some very common verbs, including the postural verbs illustrated in table 6. Singular and plural forms contrast throughout Numic, usually distinguished by reduplication or suppletion. In addition, in Northern Paiute and Central Numic, distinct dual forms have also been innovated. ${ }^{39}$ The Northern Paiute duals are sometimes identical to their Shoshoni counterparts, but in three cases, Northern Paiute has distinctive forms: aatta?a 'sit' (PL), wami 'stand' (DL), and pokkw ${ }^{w}$ 'lie' (PL) are not found elsewhere. Following Norris (1986:234-36), we interpret the relation between Northern Paiute and Mono as follows. Mono preserves the original Western Numic paradigm: plural forms were used to refer to two or more subjects, and the dual as a category did not exist. The original plurals $y \dot{t} g^{w} i$ 'sit', kono 'stand', and $k^{w}$ appi 'lie' were then respectively specialized as a dual, a plural, and a dual when the three new Northern Paiute forms were innovated. The actual source of these new forms remains a mystery, but we take the change to be a structural effect of contact with Shoshoni.

Two further lexical changes stem from an originally sound-symbolic Western Numic alternation between $* k$ and $* t s$, as reconstructed by Nichols (1974).

${ }^{38}$ For a full discussion of the comparative data, see Nichols (1974:250-81), who observes (1974:272) that in patterns of color-term formation, Mono shows more dialect diversity than any other Numic language.

39 The Mono forms in table 6 are cited from the Southern Owens Valley dialect (Norris 1986:236); the Northern Owens Valley and San Joaquin River dialects have the same paradigm (Lamb 1954; 1957:247-48). The Northern Paiute forms are reported for the northern Harney Valley dialect by Thornes (2003:419); with minor differences, these forms are also found in the northern Fort Hall and McDermitt dialects (Liljeblad 1966 and Snapp, Anderson, and Anderson 1982:62) and the southern Mono Lake dialect (our fieldwork). Thornes (2003:419) also quotes a plural alternant $w a k k^{w} a p p i$ 'lie', speculating that it may be a recent regularizing innovation or a distributive. 
In at least two cases, Northern Paiute has generalized a form with *ts. Thus, Mono retains the consonants of *akka 'red' and *attsa 'tan, brown' (e.g., San Joaquin River Mn attsabonogi 'to be copper, orange'), while in Northern Paiute, *akka has been lost and *attsa has come to mean 'red' (Nichols 1974:260), as illustrated above. Similarly, PN *ma-kkihi *ma-ttsihi 'elbow' survives in Northern Paiute only as ma-ttsihi. The velar stop is found in Mono (e.g., San Joaquin River, Southern Owens Valley ma-kkibi) and Central Numic (e.g., CTi ma-kkiippit, WSh kiipi). In both cases, the generalization of $* t t s$ is found in all Northern Paiute dialects, as far south as Mono Lake.

Finally, and perhaps most conspicuously, Northern Paiute has lost nominal case marking. Numic languages typically distinguish subjective, objective, and possessive case marking on nouns. The objective suffixes are $-a,-n a$, and $-t u$ in Southern Owens Valley Mono, for example, and $-a$, $-t t a$, and $-i$ in Western Shoshoni. In Northern Paiute, however, nouns show no case marking (Snapp, Anderson, and Anderson 1982:35 and Thornes 2003:98); subjective zero marking has been generalized to objective and possessive contexts. Case marking remains in other word classes, including articles, pronouns, and demonstratives. For example, as illustrated in table 3, Northern Paiute contrasts subjective demonstratives PROX $i$-ssu, DIST $u$-ssu vs. objective PROX $i$-kka, DIST $u$-kka. Apparently, as functional compensation for the loss of case marking, these objective demonstratives have also yielded a reduced objective proclitic $k a$ (Nichols 1974:216-17). This proclitic is found in all Northern Paiute dialects as far as we know, and it has no counterpart in Mono or Shoshoni.

6.2. Innovations shared with Shoshoni. At least six innovations are shared by all Northern Paiute dialects and found in Central Numic (or even Southern Numic) but are absent in all Mono dialects. One, a structural change in the organization of verb paradigms, has already been mentioned in 6.1: the development of distinctive dual forms of suppletive verbs. A second change also already suggested involves the plural subjective pronouns in table 4. As discussed in 5.1, Northern Paiute shares with Shoshoni and Timbisha the generalization of the ending *-mmi into the inclusive plural (NP *tammi). ${ }^{40} \mathrm{~A}$ third, minor change is intervocalic $* h$ loss in the word *sihi-pi 'willow': $h$ is retained in San Joaquin River Mn sihti-bi and Southern Owens Valley Mn (Big Pine) sihï̈-bi (Norris 1986:73), (Lone Pine) $s \dot{i} h \dot{t}-b \dot{t}$, but NP sïbi has lost it. Intervocalic $h$ is not regularly lost in other Northern Paiute words. In Central Numic, the $* h$ is also lost in Timbisha (e.g., WTi sïpi) and as a variant pronunciation in WSh (sihtipi sïpi).

A fourth innovation is morphological: the creation of an aspectual suffix -pinni found in Northern Paiute, Shoshoni, and Timbisha, but absent in Mono

\footnotetext{
40 Note that Northern Paiute has not simply borrowed the Western Shoshoni pronouns, since their second-person plural forms are based on different roots; rather, the Western Shoshoni use of the productive nominal plural ending -mmi in subjective pronouns has spread into Northern Paiute.
} 
and elsewhere in Numic. Descriptions of its function are hard to reconcile. In Northern Paiute, it has been called "general active" (Liljeblad 1966:51), "perfective-stative" (Thornes 2003:402-3), and "completive-stative" (Snapp, Anderson, and Anderson 1982:74), and it has a continuative function in Mono Lake Northern Paiute. In Western Shoshoni, it marks progressive aspect (Crum and Dayley 1993:91). In any case, the form itself is clearly an innovation shared by Northern Paiute and the contiguous dialects of Central Numic.

A fifth innovation is found in the numeral 'nine', for which all Northern Paiute dialects have a complex form simi kadu?upi 'one less' (i.e., 'than ten'). But it is also characteristic of Shoshoni to form the word for 'nine' from simi 'one', as in NSh sïmonowimihyandit (Gould and Loether 2002:98) and WSh sitmmihanti. The Northern Paiute formation is therefore not altogether independent; it must reflect Central Numic influence, even if Northern Paiute has created a distinctive formation under that influence rather than simply borrowing a Shoshoni word. ${ }^{41}$

Finally, Northern Paiute has a habitual agent nominalizer -wabi, as in pidawabi 'wife, sweetheart', literally, 'one who builds a fire' (Harney Valley) (Tim Thornes, personal communication) and yadua-wabi 'speaker, interpreter' (Yerington). This suffix has a restricted distribution in Northern Paiute but is clearly cognate to habitual agent nominalizers in Shoshoni and Comanche (e.g., WSh taikw ${ }^{w}$-woppi 'speaker, talker', NSh tiboo-g ${ }^{w}$ appi 'writer', Cm kohtoo-wapi 'fire-builder'). No other Numic language has a formally equivalent suffix. Toosarvandani (2010) argues that it diffused across already differentiated Numic languages.

6.3. Summary. As seen in 6.1, the unique innovations of Northern Paiute are more numerous than those of Mono; they include four types of change, three of which are idiosyncratic lexical or morphological innovations applying to more than one word each. The overall pattern is thus consistent with the view that Northern Paiute, unlike Mono, is a true clade within Western Numic. Still, innovations shared with Shoshoni are also conspicuous, as seen in $\mathbf{6 . 2}$ above and as we show in $\mathbf{7 . 4}$ below. Even if Northern Paiute is a clade, many of its most distinctive features arose through diffusion.

7. Crosscutting innovations in Western Numic. If features defining Mono and Northern Paiute reflect diffusion across the Western-Central

\footnotetext{
${ }^{41}$ Mono also shares with Timbisha a word for 'nine': CTi wanikki, wanikki; San Joaquin River Mn, Kings River Mn, Northern Owens Valley Mn (Benton), Fish Lake Valley, Kaweah River Mn, Southern Owens Valley Mn (Independence, Lone Pine) $k^{w}$ anikki; Southern Owens Valley Mn (Big Pine) $k^{w}$ anigi (Norris 1986:118). [kk] is clearly audible in Lamb's (1953) recording of a Southern Owens Valley speaker from Fish Springs. Because the Northern Paiute formation must be due to Central Numic influence, we cannot exclude the possibility that the Mono and Timbisha form was originally used throughout Western Numic and, therefore, we do not count it as a Mono innovation.
} 
Numic dialect boundary, we should also find some cases in which the diffusional geography does not precisely match the Mono-Northern Paiute boundary. For example, we expect to find innovations shared by Timbisha and Mono that have spread into Southern Northern Paiute, or innovations shared by Shoshoni and Northern Paiute that have spread into Mono dialects. We might also find changes that have spread from Timbisha or Shoshoni into only a subset of Mono or Northern Paiute dialects respectively, or even changes that are restricted to Southern Northern Paiute and northern Mono dialects. We discuss such patterns here; they support our general emphasis on diffusion across Numic language boundaries.

7.1. Timbisha, Mono, and Southern Northern Paiute. At least three changes are shared by Timbisha, Mono, and southern dialects of Northern Paiute. The first, illustrated in (16), involves the name of a conifer (the precise referent varies). In dialects of Northern Paiute as far north as Yerington, in at least two Mono dialects, and throughout Central Numic, this word contains the reflex of Proto-Numic nasal-grade * $* k$. Forms containing the reflex of lenis $* k$ are found in Northern Northern Paiute and Southern Numic. ${ }^{42}$ There are two reasons to assume that the form in $(16 a)$ is an innovation. First, its distribution is contiguous in southern Western Numic (Mono and Southern Northern Paiute) and Central Numic; the form in (16b) is peripheral. Second, $* k$ is required by cognates outside Numic, including Tb wohomboo-l 'bull pine' and Yaqui wóko among others; Miller (1967:50) reconstructs PUA *woko. We cannot identify the cause of this shift of consonant grade, but it may be related to sandhi gradation changes. ${ }^{43}$

$$
\begin{aligned}
& \text { (16) Numic *woyko- vs. *woko- } \\
& \text { (16a) *woyko-: SNP (Yerington) woggo-bi, San Joaquin River Mn } \\
& \text { woqqo-bi, Kings River Mn wokko-, CTi woyko-pi, WSh } \\
& \text { woyko-pi, Cm woko } \\
& \text { (16b) *woko-: NNP (Bannock, Warm Springs) wogo-, SNP (Paradise } \\
& \text { Valley) wogo-bbi (Lamb 1954), SNP (Mono Lake) wogo-bbi, } \\
& \text { Kw woho-dit-bit 'bull pine', CR oyo-mpi 'fir' }
\end{aligned}
$$

\footnotetext{
42 In both of the northern-northeastern Mono dialects, i.e., those of Northern Owens Valley and Fish Lake Valley, the attested form is wokko-bit. This would ordinarily require reconstructing *wokko- with fortis *kk (the reflex of *woyko- should be woggo-). We assume that this form has diffused from the San Joaquin and Kings River dialects to the west or from Southern Owens Valley, where the form in use is not attested in data available to us.

43 Nichols (1974:30) treats this case as metathesis of gradation between *woko- (lenis medial consonant, nasal grade on a following consonant) and *woyko- (nasal-grade medial consonant, lenis grade on a following consonant). In any case, variability along these lines is not rare. To cite examples reconstructed by Nichols (1974:317-43), Numic forms of the word for 'crow' point to *atta vs. *ata (e.g., CR atta- vs. NP ada), and forms of 'heel, ankle' point to *tampi vs. *tappi (e.g., CR tampi vs. CTi tappi-). Nichols (1974:30) writes that reflexes of *woko- survive in San Joaquin River Mono compounds. This pattern also suggests that $*_{w o \eta k o-}$ is a newer intrusion, though we have been unable to find examples in the resources available to us.
} 
A second innovation spreading into Northern Paiute from Central Numic and Mono is the loss of reduplication to express pluractionality, i.e., iteration or repetition of a verbal action (cf. English nibble, involving repeated biting actions). Southern Numic, Comanche, and the northern dialects of Northern Paiute retain productive reduplication to mark various kinds of pluractionality, as illustrated in (17). ${ }^{44}$

(17) Numic pluractional reduplication

(17a) Su=nana $u=$ bi-ppi-ma-ttattsi. SUBJ=man $3=$ RED-IP.butt-IP.hand-slap

'The man is spanking him/her'. (Thornes2003:412)

Harney Valley Northern Paiute

(17b) Hini u-waka-tu kasa-bi-piku-hki-na.

what 4-toward-along wing-RED-beat-come-conT

'Something kept coming toward him making wing noises'. (Robinson and Armagost 1990:313)

Comanche

(17c) To-dono- $k k^{w} e e-d \dot{i}=$ ina

RED-pierce-RSLTV-NOM=3sG

'He stabbed him repeatedly'. (Zigmond, Booth, and Munro 1990: 97)

Kawaiisu

In contrast, Mono Lake Northern Paiute, Mono, Timbisha, and Shoshoni rely solely on suffixes to express pluractionality; examples are given in (18). In these languages, verbal reduplication is preserved only in a few fossilized lexical items and in the suppletive forms of some verbs (table 6). The loss of pluractional reduplication must be the spreading innovation, given its contiguous distribution; the archaic system survives in peripheral dialects. ${ }^{45}$ The Uto-Aztecan antiquity of pluractional reduplication is in any case well established (Heath 1977:34-35).

(18) Pluractional suffixes in Southern Northern Paiute, Mono, Timbisha, and Shoshoni

(18a) Southern Northern Paiute (Mono Lake): -dzagatti, -bodotti 'iterative', -heggwi 'repetitive, habitual', -wintheggwi, -wintdui, -ppinni 'continuative'

44 These languages also each have at least one other suffix marking pluractionality; cf. NNP (Harney Valley) - yakkw $i$ 'habitual, continuative', $\mathrm{Cm}-? e,-? i$ 'repetitive', $\mathrm{Kw}-m i,-v i$ 'habitual'. For Northern Paiute, note that productive reduplication is explicitly described only for the Harney Valley dialect (Thornes 2003:412-14). We assume it is present in the other northern dialects too, since Liljeblad (1966) and Snapp, Anderson, and Anderson (1982) include example sentences and texts with reduplication. Our discussion of Numic pluractionality is based on an unpublished paper by Michael J. Houser, Reiko Kataoka, and Maziar Toosarvandani.

45 A notable feature of this change is that what is spreading is the loss of a morphological process, not any particular new formation. The different languages have innovated distinct formatives to replace reduplication. 
(18b) San Joaquin River Mono (Lamb 1958:266-68, 273-74): -ppa?i 'repeated', -nawi, -ya?wi 'distributive', -?. . . kki 'intermittent'

(18c) Southern Owens Valley Mono (Norris 1986:148): -ppa?i 'repeated or continuous action', -na?i 'successive action'

(18d) Central Timbisha (Dayley 1989b:56): - $P i$ 'iterative, durative', -mmi 'habitual, iterative, durative'

(18e) Western Shoshoni (Duck Valley) (Crum and Dayley 1993:90): - $P i$ 'periodic repetitive, habitual', -mmi 'habitual, iterative', $-y u$ 'iterative, repetitive', - $t \dot{t}$ 'habitual, customary'

(18f) Western Shoshoni (Gosiute) (Miller 1996:700-701): - $i$ 'keeps on; kept on . . .-ing', -mmi 'had been; used to be . . .-ing', -ppinni 'frequentative, intermittent'

(18g) Northern Shoshoni (Gould and Loether 2002:84, 137): - $i \mathrm{i}$ 'repetitive, habitual', -mi?i 'habitual, iterative', -Pai 'habitual, repeated', -de 'habitual, continual', -nna 'iterative', -git?nna 'repetitive'

A third example, related to a pattern discussed in 5.2.2 above, is an $* i \rightarrow$ *ai change shared by Mono and Central Numic. As illustrated in (19) and (20), this change has also affected the southernmost dialect of Northern Paiute in the words for 'tongue' and 'three'. ${ }^{46}$ The $* i \rightarrow * a i$ change in (19), unlike the changes discussed in 5.2.2, is not shared by Timbisha.

(19) PN *pahi- 'three'

(19a) Comparative evidence: PUA *pahi (Miller 1967:69) > Luiseño paahi (Kroeber and Grace 1960:119)

(19b) *i: NNP pahi-; SNP (Yerington) pahi-; San Joaquin River Mn pahi-; Kings River Mn pahi; Northern Owens Valley Mn pahi-; Fish Lake Valley Mn pahi-; Ti pahi

(19c) *ai: SNP (Mono Lake) pahai-, pahe-, pahi-; Southern Owens Valley Mn (Big Pine) pahe (Lamb 1953:segment 24), (Fish Springs, Independence) pahi; WSh (Duck Valley) pahai-; Kw pehe-

(20) *iko 'tongue'

(20a) *i: NNP igo, SNP (Yerington) igo

(20b) *ai: SNP ego igo (Mono Lake); San Joaquin River Mn e Kings River Mn ego; Northern Owens Valley Mn ego; Kaweah River Mn ego; Southern Owens Valley Mn (Big Pine) ai (Lamb1953: segment 25), (Fish Springs, Independence) ego; Ti eko; Sh aiko; Cm eko; Kw egu-

\footnotetext{
46 We exclude examples of pai- in various Central and Southern Numic dialects from (19); intervocalic $h$ loss makes it impossible to distinguish between pahi- and pahai-.
} 
(20c) *ai > *a: CR ayo-

7.2. Shoshoni, Northern Paiute, and northern Mono dialects. Northern Paiute shares the loss of intervocalic lenis $* w$ with all Numic languages other than Mono and Timbisha, and with the Fish Lake Valley dialect of Mono. This is shown for several examples in (21)-(23), with comparative Uto-Aztecan evidence for $*_{w}$ quoted in each case. The loss of $*_{w}$ in Fish Lake Valley Mono, shown by aa 'horn' in (21c), puts this change in the crosscutting class of innovations.

(21) Numic reflexes of PUA *awa 'horn' (Miller 1967:41)

(21a) Comparative evidence: Tübatulaal aawa-t, Rm $a$ ? wá

(21b) *awa (*w retained): Northern Owens Valley Mn awa; San Joaquin River Mn awa; Kings River Mn $a \boldsymbol{w a}$; Southern Owens Valley Mn (Fish Springs, Independence) awa; WTi awa, CTi aama

(21c) *aa (*w lost): Fish Lake Valley Mn $a a$, NP $a a$, WSh $a a$, Kw $a a-p \dot{t}, \mathrm{CR}$ aa-ppí

(22) Numic reflexes of PUA *kawi 'mountain' (Miller 1967:47)

(22a) Comparative evidence: Luiseño qawíi-ča (Elliott 1999:795), Rm kawí

(22b) *kawi $(* w$ retained): no unambiguous evidence; *kawi replaced by Mo, Ti *toya-bi 'mountain' (see 5.2)

(22c) *kai (*w lost): NP kai-ba, Kw kee-vi, CR kaiva

(23) Numic reflexes of PUA *sawi 'melt' (INTR), *sawa 'boil, cook' (TR)

(23a) Comparative evidence: Tohono O'odham haagid 'melt, thaw'

(23b) *sawa (*w retained): Mn sawa 'boil' (TR), CTi saawa 'boil' (TR), CTi sawi 'melt' (INTR)

(23c) *saa (*w lost): NP saa 'cook', WSh saa 'boil' (TR), Cm saa-pi 'boiled meat'

Relative chronology shows that $*_{w}$ loss is a recent sound change. As discussed in 2.2 and 5.2 above, Eastern Numic *ai $>a$ in Colorado River Numic; thus, PN *ati 'bow' > *aiti $>\mathrm{CR} a \check{c} \dot{t}$, as in (11). Because the *ai $>* a$ change did not affect PUA *kawi-pa 'mountain' > CR kaiva in (22c), it must pre-date $*_{w}$ loss. Therefore, because the $* a i>* a$ change is restricted to Colorado River Numic, ${ }^{*} w$ loss must be relatively recent. ${ }^{47}$

\footnotetext{
47 Jane Hill points out to us that some Takic languages have also lost intervocalic lenis $* w$. The Numic change is found in a contiguous area, but the innovation is clearly a natural one within Uto-Aztecan.
} 
7.3. Shoshoni and Northern Paiute dialects. At least one change is shared by Central Numic and some but not all Northern Paiute dialects. In the word for 'eight', northern dialects of Northern Paiute share with Northern Shoshoni and some Central Numic dialects an initial formative *nami-. Other Western and Central Numic dialects lack this prefix. Examples are shown in (24). In some dialects, the lenis $m$ has become $w$ or is lost, and original $* i$ has become $a i$ with further changes in some Central Numic dialects, along the lines of the $i \rightarrow a i$ change discussed in 5.2.2.

(24) Western and Central Numic forms of 'eight'

(24a) Forms with *nami-

(24ai) Northern Northern Paiute: Harney Valley namiwattsikk ${ }^{w} \dot{t}$ yuu, Bannock namiwattsikk ${ }^{w} i$ ? $y u$

(24aii) Central Numic: NSh nawiwatsiwitti (Gould and Loether 2002:98), Cm namewatsik ${ }^{w}$ iti

(24b) Forms without *nami-

(24bi) Southern Northern Paiute: Mono Lake wogg $^{w}{ }^{\text {ostgg }}{ }^{w} \dot{t}$ iyu

(24bii) Mono: San Joaquin River Mn wosiwiti, Northern Owens Valley Mn woosiwiddu, Southern Owens Valley Mn woottsiwi

(24biii) Central Numic: CTi woosiwiti, WSh woosiwihti

7.4. Northern Paiute and northern Mono dialects. We have found three changes that are shared by southern (or all) Northern Paiute dialects and northern Mono dialects. The first, already discussed in $\mathbf{3}$, is the change of Proto-Numic nasal-grade glides to stops: *ny $>*^{*} n t^{y}, * \eta w>*^{*} \eta k^{w}$. In this general form, the change occurred in Northern Paiute and the San Joaquin River, Kings River, and Northern Owens Valley Mono dialects. Fish Lake Valley Mono in the northeast and Kaweah River Mono in the west underwent a more limited $* \eta w>* \eta k^{w}$ change. Only Southern Owens Valley Mono was completely unaffected by nasal-grade glide obstruentization.

The other two changes are found only in the central Western Numic area, shared by southern dialects of Northern Paiute and northern dialects of Mono. One was depalatalization, also mentioned in $\mathbf{3}$ above. This targeted the output of the *ny>*nty change after the further shift of nasal-grade stops to voiced fortis stops $\left(* n t^{y}>* d d^{y}\right)$. This was then in turn affected by depalatalization: $* d d^{y}>* d d$. As illustrated in (6) and (7) and summarized in table 2, this change is seen in the Mono Lake dialect at the southern end of the Northern Paiute area and in the adjacent San Joaquin River and Northern Owens Valley Mono dialects.

A final change is the merger of PN $* \eta$ and $*_{n}$ as $n$. This took place in several discontinuous areas (Nichols 1974:66-68): in some Colorado River Numic dialects; in Kawaiisu, Comanche, and most Shoshoni dialects; and in 
San Joaquin River Mono and Mono Lake Northern Paiute. Since there is no merger in Northern Owens Valley Mono or in much of Northern Paiute, including even the southern dialect of Yerington, the relatively localized Western Numic change must be independent of the Central Numic change.

8. Summary and conclusions. Three main conclusions emerge from our study. The first concerns the formation of apomorphic linguistic taxa, that is, groups defined by shared innovations. Are such taxa formed by DESCENT (from a common ancestor in which the innovations originated) or DIFFUSION (among already differentiated languages)? For Western Numic specifically, are Mono and Northern Paiute in fact clades (as usually assumed)?

We examined innovations that differentiate these languages in $\mathbf{5}$ and $\mathbf{6}$. Table 7 is a summary. ${ }^{48}$ Isoglosses arising from some 25 innovations demarcate the two languages. Clearly, Mono and Northern Paiute are apomorphic taxa. But only 11 the changes in table 7 could be analyzed as independent innovations of Mono or Northern Paiute. A majority have diffused across the Western-Central Numic boundary. The Western Numic languages would resemble each other far more without such diffusion. This diffusional pattern is consistent with Miller's remark that Western Numic isoglosses "tend to run east and west" (Miller 1986:99) and, as noted in $\mathbf{2 . 1}$ above, it mirrors documented patterns of social interaction.

The evidence for a Mono clade is particularly weak; the unique innovations of Northern Paiute are more numerous. If the latter justify a Northern Paiute clade, a reasonable interpretation is that Western Numic was once a dialect network that included the various ancestors of Mono dialects and of Northern Paiute. In that earlier network, nascent Mono dialects were no closer to each other than they were to the ancestor of Northern Paiute. An eventual by-product of diffusion across the Mono-Timbisha (Western-Central Numic) dialect boundary was the emergence of a Mono taxon, but Mono is not a clade distinct from Western Numic and there was no Proto-Mono language. In effect, then, Northern Paiute is just an outlier Western Numic dialect that did not share the diffused innovations of what we now call Mono.

Throughout this paper, we have assumed that Western, Central, and Southern Numic are clades; the last two may form an Eastern Numic clade. A reconsideration of this standard analysis is beyond our scope in a paper focused on Western Numic dialectology, but for future consideration, it is worth highlighting the connections between Mono dialects (especially Southern Owens Valley Mono) and Central Numic (especially Timbisha). Western Numic is defined by relatively few non-lexical changes. As discussed in 3.2.1 and

\footnotetext{
${ }^{48}$ Note that we count the Mono *ai changes separately, as well as the Northern Paiute postural verb innovations. Each set is obviously related, but the individual changes are lexically irregular and neither set represents a single innovation.
} 
TABLE 7

Summary of Innovations Leading to Mono-Northern Paiute Differences ${ }^{1}$

\begin{tabular}{|c|c|c|c|c|c|}
\hline & $\mathrm{Mn}$ & NP & $\mathrm{Ti}$ & $\mathrm{Sh}$ & $\mathrm{Cm}$ \\
\hline \multicolumn{6}{|l|}{ Independent Mono innovations (section 5.1) } \\
\hline Demonstratives in $*_{-} h u$ & + & - & - & - & - \\
\hline Plural subjective pronoun leveling in favor of $*_{-} \eta w a$ & + & - & - & - & - \\
\hline Iterative -ppa?i & + & - & - & - & - \\
\hline \multicolumn{6}{|l|}{ Shared Mono innovations (section 5.2) } \\
\hline Habitual agent nominalizer $-t t \dot{t}$ & + & - & + & - & - \\
\hline Objective suffix $-n a$ & + & - & + & - & - \\
\hline toyabi for 'mountain' & + & - & + & + & + \\
\hline$* a \rightarrow * a i$ in 'bow' & + & - & + & + & + \\
\hline$* a \rightarrow * a i$ in 'daughter' & + & - & + & + & + \\
\hline$* a \rightarrow * a i$ in 'acorn mush' & + & - & n.a. & n.a. & n.a. \\
\hline$* i \rightarrow *^{*} a i$ in 'gray' and 'white paint' & + & - & + & + & + \\
\hline Absolutive $*_{-} p a \rightarrow-p a i$ & + & - & + & n.a. & + \\
\hline \multicolumn{6}{|l|}{ Independent Northern Paiute innovations (section 6.1) } \\
\hline Subjective demonstratives in $-s s u$ & - & + & - & - & - \\
\hline Color term suffix $<\mathrm{PN} *_{-\eta}$ wi-nya & - & + & - & - & - \\
\hline aatta?a for 'sit (PL)' & - & + & - & - & - \\
\hline wammi for 'stand (DL)' & - & + & - & - & - \\
\hline$p o k^{w} a$ for 'lie (PL)' & - & + & - & - & - \\
\hline Generalization of *ts in 'elbow' & - & + & - & - & - \\
\hline Generalization of *ts in 'red' & - & + & n.a. & n.a. & n.a. \\
\hline Changes related to loss of nominal case marking & - & + & - & - & - \\
\hline \multicolumn{6}{|l|}{ Shared Northern Paiute innovations (section 6.2) } \\
\hline Distinctive DL forms of suppletive verbs & - & + & + & + & - \\
\hline Leveling of inclusive PL subjective pronoun ending $*_{-} \eta w a$ & - & + & + & + & + \\
\hline Loss of $h$ in 'willow' & - & + & + & + & - \\
\hline Aspectual -pinni & - & + & - & + & + \\
\hline Numeral 'nine' formed with simi 'one' & - & + & - & + & - \\
\hline Habitual agent nominalizer -wabi & - & + & - & + & + \\
\hline
\end{tabular}

3.2.2, some of the most structurally significant innovations within Western Numic are associated with smaller groupings. We leave it to future research to determine whether Western Numic innovations as such suffice to establish an unimpeachable clade or, alternatively, as we suggest for taxa within Western Numic, whether the Western Numic taxon itself emerged out of an earlier network in which the ancestors of some Mono dialects had more in common with the ancestors of Central Numic dialects.

More broadly, we encourage historical linguists to contemplate the possibility that mismatches between apomorphic taxa and true clades are widespread, 
contrary to the usual assumption (see $\mathbf{1}$ above). If, as we have argued, taxa can be formed when innovations diffuse across pre-existing dialect and even language boundaries, then there is no reason to assume that taxonomies based merely on shared innovations must also represent true cladistic structures. We suggest that the dynamics of language contact and linguistic diffusion can obscure or even erase clades.

A second conclusion concerns the role of phonological innovations in cladistic analysis. We have examined six regular sound changes. The first two, discussed in 3.2.1 and 7.4, occurred early in the development of Western $\mathrm{Nu}$ mic dialects: *ny and * $\eta w$ obstruentization and the pan-Western-Numic change of nasal-grade stops to voiced fortis stops. The other four sound changes are later mergers: depalatalization of $* d d^{y}(\mathbf{3 . 2 . 1}$ and 7.4), the merger of fortis and voiced fortis stops (3.2.1), intervocalic $* w$ loss (7.2), and the merger of $* \eta$ and $* n$ (7.4). Interestingly, not one of these changes can be associated with any clade in Numic. In all but one case, they operate in dialects of both Mono and Northern Paiute, crossing the major Western Numic taxon boundary. The remaining case is the innovation of voiced fortis stops. We argued in 3.2.1 that this diffused across Western Numic after the obstruentization of *ny and $* \eta w$ in Northern Paiute and some Mono dialects.

The conclusion that Western Numic sound changes do not correspond to possible clades may be of general interest. Some discussions of subgrouping methodology use mostly phonological evidence; for example, Campbell's (2004:191-98) exposition of Mayan subgrouping and Hill's (2007) analysis of Uto-Aztecan subgrouping are based entirely on sound changes. ${ }^{49}$ But as Ringe, Warnow, and Taylor (2002:66-68) point out, sound changes "are usually so "natural' that they can easily be repeated in different lines of descent" and therefore "provide much less information for subgouping than might be supposed." A further confounding factor is the diffusion of sound changes across pre-existing dialect boundaries. Only two of the six regular sound changes we examined (the mergers of fortis and voiced fortis stops and of $*_{\eta}$ and $*_{n}$ ) are found in discontinuous Numic areas; the other four occur in continuous areas. This asymmetry would not be expected if all the changes had simply been "repeated in different lines of descent." We suggest that phonological diffusion too can confound cladistic analysis.

Our final conclusion is methodological. It was not uncommon in structuralist Americanist linguistics to consider each language in need of only one round of documentation, canonically yielding a grammar, dictionary, and text collection. This bias stems partly from the prevalence of family-tree models

\footnotetext{
49 Campbell does not justify his procedure. Hill writes explicitly that "most linguists agree that the only scientifically probative evidence . . . is the 'shared innovation' in sound change, or the innovation of a distinctive shared aberrancy." We consider the latter more significant than the former.
} 
in historical linguistics and the assumption that taxonomic units are clades: if languages are the key diachronic classificatory units, they may also be seen as synchronically essential. If, however, as we suggest, taxa are often cladistically epiphenomenal, to understand how they were formed, it may be essential to know their full range of dialect diversity.

In any case, our work convinces us that much can be learned from studying the dialects of even the best-studied American Indian languages. Today, of course, virtually no indigenous languages of North America retain the wealth of dialect diversity they had even a century ago, but there are many cases where dialect information can still be recorded from speakers and many others where it can be partly recovered from the rich records left by linguists and anthropologists of the Boasian and later eras.

\section{APPENDIX A}

\section{Numic Dialects and Sources}

Sources of information about Numic dialects are listed below. ${ }^{50}$ For Western Numic, we list all published sources known to us and all unpublished sources to which we have had access; recall from 3.2.1 above that the merger of fortis and voiced fortis stops defines what we call the Northern Northern Paiute dialects. For Central Numic, our coverage is relatively complete; our coverage is sparse for Southern Numic (since this is not our focus).

We cite first one primary source for each dialect shown below, followed in most cases by other sources. Throughout this paper, all otherwise unattributed forms associated with a given dialect are from that dialect's primary source; other sources are always quoted explicitly when used.

1. Western Numic (WN)

(a) Northern Paiute (NP) (ISO code: pao)

$i$. Northern Northern Paiute (NNP): otherwise unattributed forms are from Harney Valley

A. Bannock (Fort Hall, Idaho): Liljeblad (1966); also Steward (1938), Liljeblad (1950), Lamb (1954-1955:notebook W), Nichols (1974)

B. Warm Springs, Oregon: Lamb (1954-1955)

C. Harney Valley (Burns, Oregon): Thornes (2003); also Marsden (1923), Lamb (1954-1955:notebook X), Nichols (1974)

$D$. Surprise Valley (Fort Bidwell, California): de Angulo and Freeland (1929); also Kelly (1932)

E. Honey Lake (Susanville, California): Waterman (1911), Nichols (1974)

F. McDermitt, Nevada: Snapp, Anderson, and Anderson (1982)

G. Pyramid Lake (Nixon, Nevada): Natches (1923), Lowie (1924), Lamb (1954-1955:notebook B, pp. 98-141), Fowler (1972)

50 The magisterial Northern Paiute dictionary by Liljeblad, Fowler, and Powell (2012) appeared too late to be used in our work. 
ii. Southern Northern Paiute (SNP)

A. Paradise Valley (Winnemucca, Nevada): Lamb (1954-1955:notebook W); also Steward (1938)

B. Stillwater (Fallon, Nevada): Wheat (1950); also Fowler (1992)

C. Yerington, Nevada: Yerington Paiute Tribe (1987a;1987b); also Lamb (1954-1955:notebook B, pp. 142-60; unnumbered notebook, pp. 1-14)

D. Mono Lake (including Lee Vining, Bridgeport, and Coleville, California): our fieldnotes and recordings; also Barrett (1906), Steward (1933), Lamb (1954-1955: unnumbered notebook, pp. 14-52), Davis (1965)

(a) Mono (Mn) (ISO code: mnr)

$i$. San Joaquin River Mono (upper San Joaquin River watershed, including North Fork and Auberry, California): Bethel et al. (1993); also Gifford (1932), Lamb (1953-1955:segments 1-3, 23, 36-66; 1954-1955; 1957; n.d.)

ii. Kings River Mono (upper Kings River watershed, including Sycamore Valley and Dunlap, California): Lamb (1954-1955:notebook B, pp. 59-83); also Gayton (1948)

iii. Northern Owens Valley Mono: otherwise unattributed forms are from Bishop A. Benton, California: Lamb (1954-1955)

B. Bishop, California: Lamb (1954-1955:unnumbered notebook, pp. 13-35); also Steward $(1933 ; 1938)$

iv. Fish Lake Valley Mono: Lamb (1954-1955); also Steward (1938)

v. Kaweah River Mono (upper Kaweah River watershed): Lamb (1954-1955); also Gayton (1948)

vi. Southern Owens Valley Mono: otherwise unattributed forms are from Big Pine

A. Big Pine, California: Norris (1986); also Steward (1933; 1938), Lamb (1954-1955)

B. Fish Springs, California: Lamb (1954-1955); also Steward (1933; 1938), Lamb (1953:segments 24-33) ${ }^{51}$

C. Independence, California: Lamb (1954-1955); also Steward (1933; 1938), Nichols (1974)

D. Lone Pine, California: Lamb (1954-1955)

2. Central Numic $(\mathrm{CN})$

(a) Timbisha (Ti) (ISO code: par): otherwise unattributed forms are from Central Timbisha

$i$. Western Timbisha

A. Owens Lake (Lone Pine, California): Good (1964); also Rackley (n.d.), Lamb (1954)

B. Coso Range, Saline Valley, Panamint Valley (Darwin, California): Steward (1938), Shaul (1983)

ii. Central Timbisha (Death Valley, California): Dayley (1989a; 1989b); also Steward (1938)

51 Tom Stone, the Mono speaker on these recording segments, is identified by Lamb (19541955) as a native of Fish Springs living in Big Pine. 
iii. Eastern Timbisha

A. Grapevine Canyon: McLaughlin $(1987 ; 2006)$

B. Beatty, Nevada: Steward (1938)

C. Lida, Nevada: Steward (1938)

(b) Shoshoni (Sh) (ISO code: shh); see also Steward (1938) for information about other dialects

$i$. Western Shoshoni (WSh): otherwise unattributed forms are from Duck Valley

A. Gosiute: Miller (1996); also Miller (1972)

B. Duck Valley (Owyhee, Nevada): Crum and Dayley (1993)

C. Big Smoky Valley: Crapo (1976)

ii. Northern Shoshoni (NSh)

A. Lemhi Valley: Lowie (1909)

B. Fort Hall, Idaho: Gould and Loether (2002); also Steward (1938)

iii. Eastern Shoshoni (ESh)

A. Wind River: Lowie (1924)

(b) Comanche (Cm) (ISO code: com): Robinson and Armagost (1990); also Charney (1993)

3. Southern Numic (SN)

(a) Kawaiisu (Kw) (ISO code: xaw): Zigmond, Booth, and Munro (1990); also Klein (1959)

(b) Colorado River Numic (CR) (ISO code: ute): Sapir (1930; 1931)

\section{REFERENCES}

Babel, Molly. 2009. The phonetics and phonology of obsolescence in Northern Paiute. Variation in Indigenous Minority Languages, ed. Dennis Preston and James Stanford, pp. 23-45. Amsterdam: Benjamins.

Barrett, Samuel A. 1906. Translations and other fieldnotes (Yuki, Northeastern Pomo, Wasco, Klamath Lake, Northern Paiute, Modoc). Envelope \#400, Samuel Alfred Barrett Papers, BANC MSS 86/172c, Bancroft Library, University of California, Berkeley.

Bethel, Rosalie; Paul V. Kroskrity; Chistopher Loether; and Gregory A. Reinhardt. 1993. A dictionary of Western Mono. 2nd ed. Ms.

Bettinger, Robert L., and Martin A. Baumhoff. 1982. The Numic spread: Great Basin cultures in competition. American Antiquity 47:485-503.

CAmpBell, Lyle. 2004. Historical Linguistics: An Introduction. 2nd ed. Cambridge, Mass.: The M.I.T. Press.

Chambers, J. K., and Peter Trudgill. 1980. Dialectology. Cambridge: Cambridge University Press. Charney, Jean Ormsbee. 1993. A Grammar of Comanche. Lincoln: University of Nebraska Press.

Crapo, Richley H. 1976. Big Smokey Valley Shoshoni. Reno, Nev.: Desert Research Institute.

Crum, Beverly, and Jon P. Dayley. 1993. Western Shoshoni Grammar. Boise: Department of Anthropology, Boise State University.

Davis, Emma Lou. 1965. An ethnography of the Kuzedika Paiute of Mono Lake, Mono County, California. Miscellaneous Collected Papers 8-10, Anthropological Papers, vol. 75, pp. 1-56. Salt Lake City: Department of Anthropology, University of Utah.

DaYley, Jon P. 1989a. Tümpisa (Panamint) Shoshone Dictionary. Berkeley: University of California Press.

Dayley, Jon P. 1989b. Tümpisa (Panamint) Shoshone Grammar. Berkeley: University of California Press. 
de Angulo, Jaime, and Lucy S. Freeland. 1929. Notes on the Northern Paiute of California. Journal de la Société des Américanistes de Paris 21:313-35.

Elliott, Eric Bryant. 1999. Dictionary of Rincón Luiseño. Ph.D. dissertation, University of California, San Diego.

Fowler, Catherine S. 1972. Comparative Numic ethnobiology. Ph.D. dissertation, University of Pittsburgh.

1992. In the Shadow of Fox Peak: An Ethnography of the Cattail-Eater Northern Paiute People of Stillwater Marsh. Washington, D.C.: Government Printing Office.

Fowler, Catherine S., and Sven Liljeblad. 1986. Northern Paiute. Handbook of North American Indians, vol. 11, Great Basin, ed. Warren L. D’Azevedo, pp. 435-65. Washington, D.C.: Smithsonian Institution.

FreEze, Ray, AND David IAnNuCCI. 1979. Internal classification of the Numic languages of UtoAztecan. Amerindia 4:77-92.

Garrett, ANDrEw. 1999. A new model of Indo-European subgrouping and dispersal. Proceedings of the Twenty-Fifth Annual Meeting of the Berkeley Linguistics Society, General Session and Parasession on Loan Word Phenomena, ed. Steve S. Chang, Lily Liaw, and Josef Ruppenhofer, pp. 146-56. Berkeley, Calif.: Berkeley Linguistics Society.

. 2006. Convergence in the formation of Indo-European subgroups: Phylogeny and chronology. Phylogenetic Methods and the Prehistory of Languages, ed. Peter Forster and Colin Renfrew, pp. 138-51. Cambridge: McDonald Institute for Archaeological Research.

GaYton, A. H. 1948. Yokuts and Western Mono ethnography, II: Northern Foothill Yokuts and Western Mono. Anthropological Records 10:143-301.

Geraghty, Paul. 1983. The History of the Fijian Languages. Honolulu: University of Hawaii Press.

Gifford, E. W. 1932. The Northfork Mono. University of California Publications in American Archaeology and Ethnology 31:15-65.

GodDARD, Ives. 2008. Notes on Mahican: Dialects, sources, phonemes, enclitics, and analogies. Papers of the Thirty-ninth Algonquian Conference, ed. Karl Hele and Regna Darnell, pp. 246-315. London: University of Western Ontario.

Good, D. A. 1964. Western Panamint vocabulary. Catalog \#Good.001, Survey of California and Other Indian Languages, University of California, Berkeley.

Gould, Drusilla, and Christopher Loether. 2002. An Introduction to the Shoshoni Language: Dammen Daigwape. Salt Lake City: University of Utah Press.

Heath, JefFrey. 1977. Uto-Aztecan morphophonemics. IJAL 43:27-36.

HiLl, JANE H. 1978. Language contact systems and human adaptations. Journal of Anthropological Research 34:1-26. 2007. "External evidence" in historical linguistic argumentation: Subgrouping in UtoAztecan. Ms., University of Arizona.

. Forthcoming. Uto-Aztecan hunter-gatherers: Language diversity in the Takic spread and the Numic spread compared. The Language of Hunter-Gatherers, ed. Tom Güldeman, Patrick McConvell, and Richard A. Rhodes. Cambridge: Cambridge University Press.

Hock, Hans Henrich. 1991. Principles of Historical Linguistics. 2nd ed. Berlin: Mouton de Gruyter.

Hopi Dictionary Project. 1998. Hopi Dictionary, Hopìikwa Lavàytutuveni: A Hopi-English Dictionary of the Third Mesa Dialect. Tucson: University of Arizona Press.

IAnnucci, David Edmund. 1973. Numic historical phonology. Ph.D. dissertation, Cornell University.

Kaestle, Frederika, and David Glenn Smith. 2001. Ancient mitochondrial DNA evidence for prehistoric population movement: The Numic expansion. American Journal of Physical Anthropology 115:1-12.

Kelly, Isabel T. 1932. Ethnography of the Surprise Valley Paiute. University of California Publications in American Archaeology and Ethnology 31:67-210. 
KLein, Sheldon. 1959. Comparative Mono-Kawaiisu. IJAL 25:233-38.

Kroeber, Alfred L. 1907. Shoshonean dialects of California. University of California Publications in American Archaeology and Ethnology 4:66-165.

Kroeber, A. L., and George William Grace. 1960. The Sparkman Grammar of Luiseño. UCPL 16. Berkeley: University of California Press.

Labov, William. 2007. Transmission and diffusion. Language 83:344-87.

Lamb, Sydney M. 1953-1955. Mono audio recordings. Catalog \#LA 31, Berkeley Language Center, University of California, Berkeley. Online access through the California Language Archive: <http://cla.berkeley.edu/item/10099>.

. 1954-1955. Western Numic fieldnotes. Fieldnotes and microfilm in the possession of the Survey of California and Other Indian Languages, Department of Linguistics, University of California, Berkeley. 1957. Mono grammar. Ph.D. dissertation, University of California. 1958. Linguistic prehistory in the Great Basin. IJAL 24:95-100. . n.d. Monachi dictionary. Ms., University of California.

Liljeblad, Sven. 1950. Bannack I: Phonemes. IJAL 16:126-31. . 1966. Northern Paiute Manual I: Grammatical Sketch of the Northern Dialects. Boise: Department of Anthropology, Idaho State University.

Liljeblad, Sven, and Catherine S. Fowler. 1986. Owens Valley Paiute. Handbook of North American Indians, vol. 11, Great Basin, ed. Warren L. D’Azevedo, pp. 412-34. Washington, D.C.: Smithsonian Institution.

Lilueblad, Sven; Catherine S. Fowler; and Glenda Powell. 2012. The Northern Paiute-Bannock Dictionary. Salt Lake City: University of Utah Press.

Lowie, Robert H. 1909. The Northern Shoshone. Anthropological Papers of the American Museum of Natural History 2:165-306.

. 1924. Notes on Shoshonean ethnography. Anthropological Papers of the American Museum of Natural History 20:187-324.

Madsen, David B., And David Rhode, eds. 1994. Across the West: Human Population Movement and the Expansion of the Numa. Salt Lake City: University of Utah Press.

Marsden, W. L. 1923. The Northern Paiute language of Oregon. University of California Publication in American Archaeology and Ethnology 20:173-91.

McLaughlin, John E. 1987. A phonology and morphology of Panamint. Ph.D. dissertation, University of Kansas.

2000. Language boundaries and phonological borrowing in the Central Numic languages. Uto-Aztecan: Structural, Temporal, and Geographic Perspectives, ed. Gene Casad and Thomas Willett, pp. 293-304. Hermosilla: Universidad de Sonora. 2006. Timbisha (Panamint). Munich: Lincom Europa.

Merriam, C. Hart. 1955. Shoshonean tribal names. Studies of California Indians, ed. Staff of the Department of Anthroplogy, pp. 149-74. Berkeley: University of California Press.

Miller, Wick R. 1967. Uto-Aztecan Cognate Sets. UCPL 48. Berkeley: University of California Press.

1970. Western Shoshoni dialects. Languages and Cultures of North America, ed. Earl H. Swanson Jr., pp. 17-36. Pocatello: Idaho State University Press.

. 1972. Newe Natekwinappeh: Shoshoni Stories and Dictionary. Salt Lake City: University of Utah Press.

. 1986. Numic languages. Handbook of North American Indians, vol. 11, Great Basin, ed. Warren L. D’Azevedo, pp. 98-106. Washington, D.C.: Smithsonian Institution.

. 1996. Sketch of Shoshone, a Uto-Aztecan language. Handbook of North American Indians, vol. 17, Languages, ed. Ives Goddard, pp. 693-720. Washington, D.C.: Smithsonian Institution.

Miller, Wick R.; Dirk Elizinga; and John E. McLaughlin. 2005. Preaspriation and gemination in Central Numic. IJAL 71:413-44. 
Miller, Wick R.; James L. Tanner; and Lawrence P. Foley. 1971. A lexicostatistic study of Shoshoni dialects. Anthropological Linguistics 13:142-64.

Murphy, Robert F., and Yolanda Murphy. 1986. Northern Shosone and Bannock. Handbook of North American Indians, vol. 11, Great Basin, ed. Warren L. D’Azevedo, pp. 284-307. Washington, D.C.: Smithsonian Institution.

Natches, Gilbert. 1923. Northern Paiute verbs. University of California Publications in American Archaeology and Ethnology 20:243-59.

Nichols, Michael Porter. 1974. Northern Paiute historical grammar. Ph.D. dissertation, University of California, Berkeley.

Norris, Evan J. 1986. A grammar sketch and comparative study of Eastern Mono. Ph.D. dissertation, University of California, San Diego.

Pawley, Andrew, And Malcolm Ross. 1995. The prehistory of Oceanic languages: A current view. The Austronesians: Historical and Comparative Perspectives, ed. Peter Bellwood, James J. Fox, and Darrell Tryon, pp. 43-80. Canberra: Department of Anthropology, Research School of Pacific Studies, Australian National University.

Rackley, RaY. n.d. Panamint audio recordings. Catalog \#LA 51, Berkeley Language Center, University of California, Berkeley. Online access through the California Language Archive: $<$ http://cla.berkeley.edu/item/10127>.

Ringe, Don; TANDY Warnow; AND ANN TAYlor. 2002. Indo-European and computational cladistics. Transactions of the Philological Society 100:59-129.

Robinson, Lila Wistrand, and James Armagost. 1990. Comanche Dictionary and Grammar. Dallas: Summer Institute of Linguistics and University of Texas.

Ross, Malcolm. 1988. Proto Oceanic and the Austronesian Languages of Western Melanesia. Pacific Linguistics, vol. C98. Canberra: Department of Linguistics, Research School of Pacific Studies, Australian National University. . 2007. Calquing and metatypy. Journal of Language Contact 1:116-43.

SAPIR, EDWARD. 1930. The Southern Paiute language. Proceedings of the American Academy of Arts and Sciences 65:1-296. 1931. Southern Paiute dictionary. Proceedings of the American Academy of Arts and Sciences 65:537-730.

Schmidt, Johannes. 1872. Die Verwandtschaftsverhältnisse der indogermanischen Sprachen. Weimar: Hermann Böhlau.

Shaul, David L. 1983. Panamint audio recordings. Catalog \#LA 155, Berkeley Language Center, University of California, Berkeley. Online access through the California Language Archive: $<$ http://cla.berkeley.edu/item/10039>. . 1986. Linguistic adaptation and the Great Basin. American Antiquity 51:415-16.

Silver, Shirley, and Wick R. Miller. 1997. American Indian Languages: Cultural and Social Contexts. Tucson: University of Arizona Press.

Snapp, Allen; John Anderson; And Joyce Anderson. 1982. Northern Paiute. Studies in UtoAztecan Grammar, ed. Ronald W. Langacker, vol. 3, pp. 1-92. Dallas: Summer Institute of Linguistics and University of Texas.

Steward, Julian H. 1933. Ethnography of the Owens Valley Paiute. University of California Publications in American Archaeology and Ethnology 33:233-50. . 1938. Basin-Plateau Aboriginal Sociopolitical Groups. Bulletin of the Bureau of American Ethnology 120. Washington, D.C.: Government Printing Office.

Thornes, Timothy Jon. 2003. A Northern Paiute grammar. Ph.D. dissertation, University of Oregon.

Toosarvandani, Maziar. 2010. Patterns of nominalization in Numic. IJAL 76:71-100.

Voegelin, C. F. 1958. Working dictionary of Tübatulabal. IJAL 24:221-28.

Waterman, Thomas Tадвот. 1911. The phonetic elements of the Northern Paiute language. University of California Publications in American Archaeology and Ethnology 10:13-44. 
Wheat, Margaret. 1950-1952. Paviotso audio recordings. Catalog \#LA 114, Berkeley Language Center, University of California, Berkeley. Online access through the California Language Archive: <http://cla.berkeley.edu/item/10156>.

Yerington Paiute Tribe. 1987a. Paiute-English English-Paiute Dictionary. Anchorage: Bilingual Education Series.

Yerington Paiute Tribe. 1987b. Yerington Paiute Language Grammar. Anchorage: Bilingual Education Series.

Zigmond, Maurice L.; Curtis G. Booth; and Pamela Munro. 1990. Kawaiisu: A Grammar and Dictionary with Texts. Berkeley: University of California Press. 